Article

\title{
Comprehensive Approach to Relevant and Reliable Reporting in Europe: A Dream Impossible?
}

\author{
Jukka Mähönen 1,2 (1) \\ 1 Faculty of Law, University of Oslo, 0162 Oslo, Norway; jukka.mahonen@jus.uio.no; Tel.: +47-22-85-95-34 \\ 2 Faculty of Law, University of Helsinki, 00014 Helsinki, Finland
}

Received: 27 November 2019; Accepted: 18 June 2020; Published: 30 June 2020

check for updates

\begin{abstract}
Corporate reporting and governance are interlinked: Accounting and reporting inventions created the modern company, and without the modern company there is no entity from which to report. Due to its raison d'etre, reporting remained finance-centered, to protect financial capital providers. From the 1970's, the question of the interests of 'stakeholders' emerged, with attempts of 'social reporting', 'corporate social responsibility', 'environmental', and 'social and environmental' and finally 'integrated' accounting and reporting. These trends are reflected also in the European Union legal framework, both in regulation of especially financial intermediaries and the 'non-financial' reporting. This article is based on an extensive literature review, research conducted in the Sustainable Market Actors for Responsible Trade (SMART) project, and socio-legal and economic empirical research based conceptual analysis of the impact of these reporting systems and their relationship to financial accounting and reporting. The result of the research is that sustainability is reduced to focus on institutional investors and other members in the investment supply chain, and climate change issues only, and new regulatory solutions are required. Based on the most recent developments in EU law and in European jurisdictions, possible paths forward are envisaged to encourage sustainability in reporting and assurance, and through that, in governance. As an outcome a set of regulatory reform proposals are given based on the SMART recommendations.
\end{abstract}

Keywords: reporting; governance; financial reporting; sustainability reporting; sustainability

\section{Introduction}

Financial reporting is the cornerstone of traditional corporate infrastructure and accordingly, of capitalism itself. Today's capitalism would not even exist without financial reporting, produced by accountants according to national or international accounting standards and reviewed by audit firms according to audit standards. By tradition, this convention and standards-based reporting is to serve creditor and minority shareholder protection and management of conventional business risks. Due to public pressure from the 1970's, both in governance and reporting, the question of the interests of 'stakeholders' emerged, those heterogeneous groups or individuals with their private interests who can affect or are affected by the achievement of the firm's objectives [1] (p. 46). At the same time, different kind of private-originated attempts of 'social reporting' and 'corporate social responsibility' reporting emerged, followed by an urge towards 'environmental' reporting, evolving into all sorts of 'social and environmental' accounting and reporting systems (SEA's and SER's) [2]. Another thread in reporting has been environmental reporting as 'sustainability reporting' [3]. Organisations have come under pressure to adapt their business practices to consider the increasing public awareness of 'environmental, social and governance' (ESG) issues.

During these formative years, financial reporting based on financial accounting conventions and standards has been complemented but not replaced by these types of compartmentalised sustainability mechanisms. 'Integrated reporting', a visualisation of how an organisation creates value to providers 
of financial capital, is the most recent addendum to, but not a replacement of, the array of reports. These trends, with sets of compartmentalised financial reporting, social reporting and environmental reporting and introduction of integrated reporting, have been reflected also in legal frameworks. In other words, this has not only made inroads in self-regulatory frameworks such as financial reporting and environmental and social reporting standards, but also in regulation of especially financial intermediaries and the so called 'non-financial' reporting. As an example can be mentioned the European Union legal framework for financial and 'non-financial' reporting, based on the 2013 EU Accounting Directive [4] and the IAS Regulation [5] introducing the International Financial Reporting Standards (IFRS), the audit according to audit standards (both national and international as International Standards of Audit), based on the Auditing Directive [6]. The EU's willingness to reform in this area is signaled through the Sustainable Finance Initiative [7], the European Green Deal [8] and the European Green Deal Investment Plan [9].

However, if commitments to sustainability are taken seriously and are to be turned into action, many issues in financial accounting itself must be tackled, for instance measurement, such as the mark-to-market accounting rules for assets held in long-term portfolios in financial accounting (as in the IFRS) [10] (p. 48). For this reason, specific sustainability indicators are essential for setting targets, monitoring progress, and determining relative performance. At the same time radical changes in the institutional and economic structure of the society must be critically assessed [11,12]. To ensure reliability, assurance and audit questions should be also discussed. In this discussion, special attention should be given to the modern reality of digitalization-based global value chains and small and medium enterprises participating in them, with a critical view to traditional reporting and governance mechanisms based on formal group structures with parent companies and subsidiaries. In the context of financial markets, traditional methods for promoting more informed investments are likely to be deficient in tackling the most pressing social and environmental concerns, bound with existing market structures emphasising agency relationships, their problematic aspects, especially information asymmetries, and with disclosure and transparency requirements perceived as solutions.

In the EU Research and Innovation programme Horizon 2020 Sustainable Market Actors for Responsible Trade (SMART) project [13] and in several of its events [14] possible paths forward in reporting and through that, in organizations' governance, have been envisaged to encourage true sustainability based on planetary boundaries, the processes that regulate the stability and resilience of the Earth system [15], and the social foundation of a just and safe space for humanity [16]. To ensure reliability, assurance and audit questions have also been discussed. Special attention has been given to the modern reality of digitalization-based global value chains indicated above.

In this SMART project research paper, as a continuation of the SMART introductory reporting reform proposals from November 2019 [17] and revised in May 2020 [18], the development of sustainability and other 'non-financial' reporting issues is discussed. Attention is given to the Global Reporting Initiative (GRI) [19], comparing it with integrated reporting as it is seen in the leading International $<\mathrm{IR}>$ Framework by the IIRC and in $<\mathrm{IR}>$ 's core, the 'integrated thinking', as well the philosophies behind it, and its possibilities as a driver for sustainability [20]. As an outcome, concrete and detailed reform proposals are given, based on the detailed SMART project proposals published in May 2020 [21].

This research is based on an extensive literature review, research conducted in the SMART project, and a socio-legal and economic empirical research based conceptual analysis the impact of these reporting systems and their relationship to financial accounting and reporting.

\section{The Power Struggle: Financial and Non-Financial Reporting}

\subsection{Introduction}

Financial reporting is the cornerstone of traditional corporate infrastructure and accordingly, of capitalism itself. Today's capitalism would not even exist without financial reporting [22]. 
Corporate reporting and corporate governance are interlinked: modern accounting and through that corporate reporting, developed from the end of fifteenth century for instance in Venice, England, and the Netherlands, made it possible to create the modern company. Without the modern company there would have been no entity on which to report [23], with the separation of capital from income distinguishing a company from a partnership [24] (p. 211). Due to these origins, corporate reporting has been centered to the provider of financial capital $[20,25]$, and to create classifications between different groups of capital providers, including controlling shareholders, minority shareholders or creditors, based on taxonomies of the financial assets they provide to the enterprise, classified as equity, debt, or derivatives [26], and to serve and protect them [27]. Due to this, the corporate reporting view has been always the one of a financial capital provider, to count the 'value' of their investment to them, and the surplus distributable, as the difference of commodities sold and factors of production paid.

Capitalism is based on financial accounts prepared according to financial accounting standards prepared by audit firms (such as the International Accounting Standards Board's (IASB) International Financial Reporting Standards, IFRS) and reviewed by audit firms based on audit standards also prepared by audit firms (such as the International Auditing and Assurance Standards Board's (IAASB) International Standards on Auditing, ISA). This in turn produces publicly reported financial performance metrics, supposedly to provide investors with information they need to make informed decisions, aiming to serve creditor and minority shareholder protection and management of conventional business risks in path-dependent, obsolete ways. Companies are obligated to follow this practice to have access to capital markets, with a vast social infrastructure of securities regulators, accounting and auditing standard setting bodies, auditing firms, and their oversight bodies. At the same time, this traditional standard based financial reporting that derives in its basics from the late fifteenth century and in its present consolidated form from the first half of twentieth century, fails to grasp modern society and economy.

It reflects in large part the industrialization era business models, based on measurements of tangible assets. Intellectual, human, and social capital [20] is ignored, recognised only exceptionally if fulfilling the requirements of an 'intellectual asset' [28]. We are increasingly living in the knowledge era, and most of the assets are intangibles or knowledge based (patents, trademarks, software, and similar) [29] (p. 109). Around 1975 the intangible assets of business entities represented around 17 percent of the market capitalization of listed companies, while today they account for approximately 84 percent. In other words, valuation of companies over time has privileged intangible 'capitals' [29] (p. 113). Investors are increasingly looking for firms to generate forms of value creation that go beyond strictly profits: longevity of firms is more and more dependent upon factors like attraction and retention of talent, friendly relationships with neighbouring stakeholders, ability to manage and keep personnel satisfied with their jobs, in addition to the ability to raise funds and operate equipment. Information on value creation drivers are required by investors and creditors not only in terms of past performance but also as critical issues for the future sustainability of firms [29] (p. 109). Externalities, both positive and negative, strongly influence the intangible value or goodwill of companies [29] (p. 113).

Due to public pressure from the 1970's, both in governance and reporting, the question of the interests of 'stakeholders' has emerged, as a late example the UK 2006 Companies Act section 172 'enlightened shareholder value' (ESV) [30]. At the same time, different kind of private-originated attempts of 'social reporting' and 'corporate social responsibility' reporting emerged, followed by an urge towards 'environmental' reporting, evolving into all sorts of 'social and environmental' accounting and reporting systems (SEA's and SER's). Another thread has been environmental reporting as 'sustainability reporting'. In sustainability reporting, social reporting and environmental reporting have not, however, met. Further, due to the externalities caused by organisations, they have come under pressure to adapt their business practices to consider the increasing public awareness of 'environmental, social and governance' (ESG) issues. As a minimum, organizations should be transparent on their ESG performance [31] (p. 276). 
A partial answer has been all kinds of 'triple bottom line' (TBL), 'corporate social responsibility' and 'sustainability' reports and their standardizations, such as the Global Reporting Initiative (GRI) and International Organization of Standardization (ISO) standard 26000, referred to also in the European Union's directive 2014/95/EU amending Directive 2013/34/EU (the Accounting Directive) on 'non-financial reporting' (the so called Non-Financial Reporting Directive) [32]. However, sustainability and 'non-financial' kind of reports remain easily superfluous compared to the organisations' financial reports. Social, environmental and sustainability reporting is not reflected in accounting, although 'sustainability accounting', an accounting system that accumulates information systematically for sustainability reporting, should be a natural evolution of sustainability reporting [33]. On the other hand, due the lack of a sustainability accounting basis, an underlying accounting system that continuously records and updates information, sustainability reporting remains superfluous and with limited assurance. Due to lack of common basis, sustainability reports lack a means for comparison over time and among companies. As there is no systematic approach to the preparation of sustainability reports, reporting is often motivated by 'cherry picking': companies' tendency to project a positive image of their sustainability efforts [34].

As sustainability reports have their greatest focus on risk management and protecting the company's reputation, they can only operate within a weak sustainability paradigm that doesn't 'push corporations to radically rethink their operations (and even existence) and move towards sustainability in any meaningful way' [34] (p. 126)]. These concerns are consistent with the view that 'corporate social responsibility' in general has been taken over by corporations as a managerial tool to manage risks and further marketing goals, as opposed to expectations of incorporating sustainable development into company values and operations [34] (p. 126)]. Further, discussion of 'sustainability' in accounting and reporting is not usually about sustainability at all. What is often presented in the reports concerns narrow environmental aspects of sustainability as climate change, if that, and without a proper consideration of all relevant environmental and social aspects. The absence of systematic considerations of social aspects of sustainability is evident [35] (p. 281). The basis of modern sustainability thinking, with the planetary boundary's framework and a safe and just operating space for humanity (social foundation), is virtually unknown to the accounting world [35] (p. 282).

Through these trends, financial reporting based on financial accounting has been complemented but not replaced by these types of compartmentalised sustainability mechanisms. Sustainability reporting has been seen partly as genuine attempts to answer to the sustainability challenges we face. However, they have remained reactionary and weak answers to sustainability, as they do not facilitate those fundamental changes that are required if the social, environmental, and economic threats to planetary boundaries and the social foundation are to be properly addressed. Sustainability reporting does not engage with sustainability as a 'post-normal', complex challenge encompassing intractable uncertainties, with high and uncertain decision stakes [36] (p. 1121).

Compared to financial, social, environmental and sustainability reporting, the International Integrated Reporting Council's [37] (IIRC) International <IR > Framework [20] is, however, something totally different. It is not a sustainability report at all, rather, it is a market-led attempt to promote a different way of thinking about corporate success and reporting [38] (p. 23). As described by the former CEO of the IIRC, 'IR is a market -led response to the corporate reporting challenges of the twenty-first century. Businesses require an evolution in the system for reporting, facilitating, and communicating mega-trends without the complexity and inadequacy of out-of-touch reporting requirements' [39] (p. vi). However, neither here has true sustainability has been taken seriously, and certainly not in a comprehensive way. Even the at the first sight the most promising attempt, 'integrated thinking' and 'integrated reporting' (for instance in South African King codes and in the International <IR> Framework), is financial capital provider centered, seeing other 'capitals' as humans and communities and the nature itself only as factors of production for the benefit of the financial capital providers (shareholders and other investors). 
These trends, compartmentalised financial reporting, social reporting and environmental reporting and the introduction of integrated reporting, have been reflected also in the European Union (EU) legal framework. In other words, this has not only made inroads in the self-regulatory frameworks of financial reporting and environmental and social reporting standards, but also in the regulation of especially financial intermediaries and the so called 'non-financial' reporting, notably the Non-Financial Reporting Directive [32], and the European Commission non-binding 'guidelines' for this Directive [40,41]. The trend is, however, to raise the thresholds for reporting units, excluding most enterprises, despite their crucial role in value chains. In the recent European Commission's Action Plan: Financing Sustainable Growth [7] (p. 10), the Commission's proposals for implementation measures and the work done in Technical Expert Group on Sustainable Finance (TEG), sustainability governance and reporting is reduced to concerning institutional investors and other members in the investment supply chain, and about climate change issues only. Although important issues, this is not at all sufficient to facilitate the implementation of sustainability throughout global value chains.

\subsection{Financial Reporting}

Sustainable financial reporting is a paradox: financial accounting is doomed to fail in taking into consideration sustainability issues as it is based on the premise of not taking into consideration externalities. In financial accounting any activity of the accounting entity that does not impact its own financial position or performance is ignored despite the negative or positive impacts that might be imposed upon others. This means that the externalities caused by reporting entities will typically be ignored, and that performance measures (such as profitability) are incomplete from a broader societal (as opposed to a 'discrete entity') perspective [42] (p. 439), [43] (pp. 449, 451). Internalising externalities in financial accounting would require an overhaul of the concept of cost, including a 'sustainable cost' [44].

Excluding externalities is understandable, taking into consideration financial accounting's purpose. According to IFRS, the objective of 'general purpose financial reporting' is to provide financial information about the reporting entity that is useful to existing and potential investors, lenders and other creditors in making decisions relating to providing resources to the entity. That involves decisions about: (a) buying, selling or holding equity and debt instruments; (b) providing or settling loans and other forms of credit; or (c) exercising rights to vote on, or otherwise influence, management's (includeing the board's) actions that affect the use of the entity's economic resources [45] (para. 1.2). General purpose financial reports provide information about the financial position of a reporting entity, which is information about the entity's economic resources and the claims against the reporting entity. Financial reports also provide information about the effects of transactions and other events that change a reporting entity's economic resources and claims. Both types of information provide useful input for decisions relating to providing resources to an entity [45] (para. 1.12). Existing and potential investors, lenders and other creditors are the primary users to whom general purpose financial reports are directed [45] (para. 1.5). Other parties, such as regulators and members of the public other than investors, lenders, and other creditors, may also find general purpose financial reports useful. However, those reports are not primarily directed to these other groups [45] (para. 1.10).

The IFRS embraces a pure shareholder primacy perspective with a narrow notion of accountability. Under this framework, accountability is only due to investors, lenders, and other creditors. It is not developed to provide information to 'stakeholders' who do not have a financial interest in an organisation, or who have an interest in other non-financial aspects of an entity's performance [43] (p. 452). Shareholder primacy is indicated in the IFRS definitions of 'assets', 'liabilities', 'equity', 'income', and 'expenses.' For example, an asset is defined as a present economic resource controlled by the entity because of past events [45] (para. 4.3). An economic resource is a right that has the potential to produce economic benefits [45] (para. 4.4). 'Control' is a central attribute of the asset definition. According to the IFRS control links an economic resource to an entity. Assessing whether control exists helps to identify the economic resource for which the entity accounts. For example, an entity may 
control a proportionate share in a property without controlling the rights arising from ownership of the entire property. In such cases, the entity's asset is the share in the property, which it controls, not the rights arising from ownership of the entire property, which it does not control [45] (para. 4.19).

Externalities typically are imposed upon social and environmental resources and current and future generations of people. If the resource, such as the air, a river or an ocean, or people, are not in the entity's 'control', it cannot be recognised as the entity's asset, meaning that its consumption or use will not be considered as an expense of the reporting entity unless fines, damages or other costs based on causing the externality are imposed by the legal system. Accordingly, any reduction in the quality of environmental resources or the health or wellbeing of people is not recognised by the entity (again, unless for example fines are be imposed, or unless the organisation makes a specific commitment to repairing the associated damage) [43] (p. 453).

'Expenses' are defined as decreases in assets, or increases in liabilities, that result in decreases in equity, other than those relating to distributions to holders of equity claims [45] (para. 4.69). Following the residual claim doctrine of Jensen and Meckling, an 'equity' is defined as the residual interest in the assets of the entity after deducting all its liabilities [45] (para. 4.63). Equity claims are defined as claims on the residual interest in the assets of the entity after deducting all its liabilities. In other words, they are claims against the entity that do not meet the definition of a liability. Such claims may be established by contract, legislation or similar means, and include, to the extent that they do not meet the definition of a liability: (a) shares of various types, issued by the entity; and (b) some obligations of the entity to issue another equity claim [45] (para. 4.64). Given that the recognition of assets relies upon 'control', then people in affected communities and environmental resources such as air and water are shared and not controlled by the organisation and hence cannot be assets. Therefore, their use and abuse are not considered 'expenses' from a financial reporting perspective. This restricts the potential of financial reporting to record costs associated with social and environmental implications of an entity's operations [43] (p. 453).

In the absence of mechanisms (such as environmental damage rules) that internalise costs (that is, bring them within the control and/or accountability of the reporting entity), the social and environmental costs are borne by the community. Those costs are not borne by the producers and consumers of the entity's goods and services and are thus not reflected in product prices. Not only does the system of financial reporting fail to give recognition to many adverse externalities, it also acts to discourage entities from contributing to sustainability. For example, organisations which invest in clean or renewable production methods may be disadvantaged in terms of their reported profits. This provides a disincentive for investment in 'clean' technologies [43] (p. 453).

As an example, can be mentioned IFRS 9 Financial Instruments. The European Parliament's resolution on IFRS 9, adopted on 6 October 2016, raised concerns about the impact IFRS 9 might have on long-term investments [46]. Both in its interim report [47] (p. 29) and its final report [10] the EU High-Level Expert Group on Sustainable Finance (HLEG) expressed its concerns on the Standard, stating in the final report that '[i]n the context of long-term investments, there is a debate about whether the new IFRS9 accounting standard on financial instruments is potentially challenging for such investments, particularly equity instruments. This is relevant for the transition towards a more sustainable economy since large-scale long-term investments are required, and because equity investment has a particularly relevant long-term risk-return profile and is needed alongside debt investment in the economy' [10] (p. 56).

\subsection{Sustainability Reporting}

\subsubsection{From Social and Environmental Accounting to Sustainability Reporting}

Due to the inescapable externalities caused by business organisations, they have come under pressure to adapt their business practices to consider the increasing public awareness of environmental, social and governance (ESG) issues. As a minimum, organisations are required be transparent on their 
ESG performance [31] (p. 276). In reporting, the unsustainability of financial reporting has been met by increased investor demands and attempts to integrate both 'stakeholder' and ESG considerations into investment, and value creation decision-making processes in businesses [2] (p. 24). Phases in this saga [2] include the mostly UK based social and environmental accounting (SEA), social and environmental reporting (SER) movements, beginning as social accounting in the 1970's, sometimes called 'corporate social responsibility' (CSR) reporting and enlargement to environmental accounting in the 1990's [48], reporting of social, environmental and financial considerations coined as 'triple bottom line' (TBL) by John Elkington in 1997 [49], and 'sustainability reporting' [50], [11] (p. 1186), finally captured by the United States (US) based Global Reporting Initiative (GRI) [19] founded in 1997, as well as the International Organization of Standardization (ISO) standard 26,000, both referred also in the Non-Financial Reporting Directive [32] as 'non-financial reporting'.

However, the main problem is that-Due to lack of true sustainability basis in them-Sustainability in these reports has remained biased, emphasizing eco-efficiency in their best [51] (pp. 23-24). The meanings of sustainability, corporate social responsibility and related terms are ambiguous, and companies are often uncertain how to define and implement sustainability [52] (p. 130). For instance, the GRI has been seen from its beginning as flawed towards social equity and human rights [3] (p. 122), and as such representing a weak form of sustainability [3] (p. 130). The GRI framework provides standardisation by requiring participants to report on economic indicators, environmental compliance, labour practices, human rights, society and product responsibility, but within these categories and subcategories, the framework allows each company the flexibility to report on issues of most salience for the company and its perceived stakeholders [52] (p. 130). At its best a traditional sustainability report is more a political 'means towards more sustainable societies', rather than being about improving reporting quality to support sustainable financial investment and business model decisions, which are supposed to be the ultimate purpose of the 'sustainability' reports of business firms [53] (p. 49). In its worst it communicates a weak sustainability, business case only, entrenched in the technocentric worldview of humans' exploitation and control over nature, with little mention of sustainability science and planetary boundaries [52] (pp. 138-139, 143).

In practice sustainability reporting was reduced to a tool of the CSR movement focussing corporate attention not only on shareholders but also corporate activities' environmental, social and ethical contexts [54] (p. 362), [55] (p. 319), [56] (pp. 783-784), emphasising the 'S' in the ESG, through the requirement to take into consideration the interests of the firm's 'stakeholders'. The CSR approach has affected not only corporate governance models but corporate governance codes themselves [56]. The normative struggle between shareholder view and stakeholder view can be seen even in the UK legal discussion on the enlightened shareholder value (ESV), based on the UK Companies Act 2006's 172 [30,57-60].

The discussion on ESV shows, however, clearly the problem of a stakeholder approach, with stakeholders having only instrumental value to the shareholders, instead of having a value of their own [61] (p. 116-117), [62] (p. 134). This is illustrated also by the 'CSR industry': consultants, NGO's, professional bodies, governmental bodies, and public relations experts trying to sell in their part the idea of socially responsible behaviour as a tool enhancing shareholder value [62] (p. 134). The CSR discussion shows also its nature as a business case, making sustainability serve shareholder value maximization, as a shareholder-centrist approach to stakeholders helps the firms' board and management avoid a conflict of objectives arising from the consideration of the firms' heterogeneous target groups by concentrating on the interest of the firms' 'owners' and how the organisation generates value to them [31] (p. 276). (I have placed 'owners' in quotation marks, as inn limited liability enterprises such as companies and cooperatives, the shareholders and members do not own the corporate assets as the entity itself owns its own assets, with the shareholders and members having decision-making rights and economic rights in the entity.) As a consequence, an ambiguity and an emptiness of 'sustainability' concepts in reporting can be seen during the last decades, reflected also in the discussion on the difference between weak and strong sustainability $[3,12,63,64]$ (p. 132). 
Weak sustainability builds on a 'business as usual', on a strong belief in technological and innovative solutions for environmental problems and the shortage of raw materials, as technological progress is assumed to continually generate technical solutions to the environmental problems caused by the increased production of goods and services (techno-optimism) [64,65] (p. 132). It relies mostly on reporting and transparency, which comprise fundaments of modern risk management and investor governance [12]. In weak sustainability, reduction of natural assets from geology, soil, air, water and all living things ('natural capital' or 'ecosystem services') can be compensated through increase in manufactured capital, or other sources of capital, such as human capital or social and relationship capital [25,64-68].

In contrast, strong sustainability questions the existing dominant market structures and pleads for more radical transformations, as conventional economics does not adequately reflect the value of essential factors like clean air and water, species diversity, and social and generational equity [69]. In strong sustainability offset between capitals is not acceptable as critical natural capital cannot be replaced by other forms of capital due to uncertainty about ecosystem functions, the irreversibility of some components of natural capital if damaged, and the aversion felt by many people about environmental degradation [64] (p. 132). Ultimately, if planetary boundaries are breached, no forms of natural capital are substitutable. Rather than viewing three 'pillars' of sustainability (social, ecological, economic) as three distinct but complementary dimensions of sustainable development [64], for instance from the reporting and disclosure points of view, the stronger model of sustainability presupposes that economic activities serve a socially just society and that both can exist only within the planetary boundaries, seeking to integrate enterprises into socio-ecological systems, so that the patterns of production and consumption to which the company contributes are within the boundaries [12].

\subsubsection{Global Reporting Initiative}

The GRI is the most widely used guidance for sustainability reporting and considered to be the de facto standard for sustainability reporting. It aims to provide for sustainability reporting what financial reporting standards such as the United States' Financial Accounting Standards Board's (FASB) generally accepted accounting principles (US GAAP) or the IASB IFRS's provide for financial reporting, and to harmonise the confusing field of sustainability reporting standards and frameworks [70] (p. 99). However, it has at least partly betrayed its original promises [71] (p. 495). Originally the GRI engaged with a broad stakeholder base including large companies, the financial sector, the accounting profession, civil society, environmental and human rights non-governmental organisations (NGO's), organised labour, and others, to strengthen civil-private regulation and collaborative governance in order to shift the balance of power in corporate governance toward civil society and make corporations accountable to all stakeholders, not only those in the 'investment supply chains' [71] (p. 496), like the International $<\mathrm{IR}>$ Framework for instance is [33] (p. 131), [71] (p. 504).

Later, however, the GRI has been criticised for moving its institutional logic over the years away from empowering civil society and other actors to be dominated by a 'corporate social performance' (CSP) logic [70] (p. 90), [71] (p. 504). GRI has been criticised forn 'its apparent reluctance' to provide a definition of sustainability, sustainable development or 'sustainability principles'. This has led to concerns that companies could sell their GRI compliant report as a sign of 'sustainable behaviour' based on an assumption that that any references to the economic, the social and the environmental and their integration is consistent with sustainability or sustainable development [51] (p. 19). The GRI has been accused of abandoning its original idea of stakeholder accountability to a shift toward 'business case', emphasising the instrumental value of reporting to corporate boards and management, the investor community, as well as auditing and consulting firms, dominated by business logics and interests [35] (p. 1122). The GRI has been seen to change its primary purpose from empowering communities, consumers, non-governmental organisations and social investors to hold corporations accountable, to the corporations themselves, in order to increase the use of their reporting standards [33] (p. 132). The end result is that while the GRI has successfully become institutionalized, its instrumental value 
for private regulation is seen as modest, as it is adjusting to markets of weak sustainability without demands of substantial accountability [71] (p. 495). Even more, they are seen more symbolic, 'as a form of insurance against future negative events', focused almost exclusively on positive information.

Due to the power used by a dominant constituency of multinational companies, financial institutions and international management and accounting consultancies, the GRI has been seen to primarily become a tool for sustainability, reputation and brand management by companies [71] (p. 505). The roles of consultancies, among the auditing firms and especially the Big 4 cannot be underestimated: regardless of which standard a corporation chooses (or is required) to use, it will likely need assistance from consultants to create the report and from auditors to provide verification services for those reports. It may even be stated that these consultants and assurance providers derive more economic benefit from the GRI than any other stakeholder [33] (p. 133). It is not surprising that the Big 4 promotes also strongly the $<\mathrm{IR}>$; auditors are benefiting from integrated reporting as it constitutes a new (assurance and consulting) market for them. The various publications of Big 4 accountancy firms in which they express the need for integrated reporting are an indication of this [72] (p. 373).

The GRI is criticised also for its failure to harmonise the multitude of sustainability reporting standards and frameworks. To the contrary, the argument goes that it has contributed to the competition among reporting guidelines for legitimacy and visibility [71] (p. 495), a competition that some critics see a 'race to the bottom' [33] (p. 132). As corporations feel greater pressure to produce sustainability reports due to concerns about mandatory reporting requirements and greater pressure from investors and NGOs, they seek to adopt the most lenient standard and the standards setters compete to provide that standard. In the end of the day, the standard that requires the least amount of information and gives the corporation the greatest ability to disclose selectively and strategically will dominate [33] (p. 132).

On the other hand, it may seem that not all 'stakeholders' care, as these symbolic actions, as opposed to true commitments to transparency, appear to work as, 'the other actors in the sustainability reporting organisational field seem to reward disclosures of any quality' [33] (pp. 129-130). Supporting this acceptance of symbolic actions are those organisations in the 'corporate social responsibility' field that rank corporations on the quantity of their disclosures, the number of indicators reported against, and not the actual performance of the company. 'Thus, simply reporting on more indicators-regardless of whether those disclosures are selective and actually work towards creating a misleading impression of the company's efforts and performance-can allow a corporation to be seen by stakeholders as working towards sustainable development' [33] (p. 130).

The GRI Framework incorporated many of financial accounting conventions, such as 'materiality' as a 'threshold concept', reliable measurement, completeness, reporting 'boundaries', and so forth. The problem is that these terms have a great deal of meaning in financial reporting and some of the meaning have been carried across to 'sustainability reporting' thus limiting the scope of disclosures that could be made [43] (p. 457). The general expectation is that civil society and market pressure will act as a countervailing force, making executives take greater account of sustainability. This explains why, to date, the legislative response to corporate unsustainability has mainly taken the form of a patchwork of mandatory and voluntary reporting requirements at the national and supranational levels [73]. This pragmatic approach reflects a persistent belief in the self-correcting properties of fully informed markets. The aim is to harness the full range of market forces to bring the operation of corporate groups and global value chains into line with social expectations in relation to sustainability.

\subsubsection{Hopeless Endeavour?}

In spite of good intentions of bringing sustainability concerns into the boardroom, and much hard work in this area, reporting requirements have so far proven to be insufficient to overcome pressures for short-term shareholder value and to influence corporations and their investors to prioritise sustainability. Notably, while the new EU non-financial reporting requirements as the Non-Financial Reporting Directive [32] and the European Commission guidelines on it [40,41] may be perceived as an intermediary step towards the internalisation of social and environmental impacts, they currently 
lack the scope and the necessary verification requirements to be a real game-changer [74]. At the global level, the weaknesses are even more pronounced, with reporting driven by voluntary and discretionary measures, leading to risks of corporate capture, lack of comparability, lack of consistency, and uncertainty in benchmarking [71]. The recent Recommendations of the Task Force on Climate-Related Financial Disclosures (TCFD) are a perfect example of this, being highly ambitious, and receiving widespread support from business, but very difficult to operationalise [75].

There is little coherent and stringent regulation of sustainability reporting and no requirements for external verification of sustainability claims. The result is a great deal of 'noise', which must be filtered by those who want to express their preferences as consumers or shareholders, with most of this promotional material being at worst green-washing, or, more recently, 'SDG-washing', and at best well-intended initiatives that are insufficient to mitigate the unsustainability of 'business as usual'. Sustainability reporting as the GRI has not been able to respond to the challenges not grasped by financial accounting relating to the planetary boundaries and social foundation for humankind, remaining a reactionary and weak answer only to sustainability without offering fundamental changes that are required if the wide-ranging and overwhelming risks to planetary boundaries and the social foundation were to be properly addressed.

\subsection{Integrated Reporting: A New Hope?}

\subsubsection{Need for Integration}

So, it is no wonder that a more 'integrated' view to the capitals and reporting has been looked for, a view than can be described as 'integrated thinking' of governance and, following from that, an 'integrated reporting' [74,76-81]. Sustainability has been included through integrated reporting also in the corporate governance codes, especially in Africa (South Africa) and Asia (Malaysia [82] and Philippines [83]). For example, the South African 'King reports' on corporate governance connect the use of integrated reporting to report on an organisation's corporate governance practices and economic-social-environmental triple-bottom-line performance [84]. However, these kinds of integrated reports have remained superfluous compared to the organisations' financial reports or even attempts for sustainability reports. As sustainability reports have their focus on risk management and protecting the company's reputation, they can only operate within a weak sustainability paradigm that doesn't 'push corporations to radically rethink their operations (and even existence) and move towards sustainability in any meaningful way' [33] (p. 126). These concerns are consistent with the view that 'corporate social responsibility' in general has been taken over by corporations as a managerial tool to manage risks and further marketing goals, as opposed to expectations of incorporating sustainability into company values and operations [33] (p. 126). Secondly, discussion of 'sustainability' in accounting and reporting is not usually sustainability at all, inter alia due to the negligence of social aspects emphasised in social and environmental accounting and reporting. What is often presented concerns environmental aspects of sustainability, and only some of them. In sustainability reporting such as the GRI the absence of systematic consideration of especially social aspects of sustainability is evident [34] (p. 281).

However, as a new leading model and as a comparison to both financial accounting, social and environmental accounting and sustainability accounting frameworks, a novel normative framework, the International Integrated Reporting Council's [85] (IIRC, previously International Integrated Reporting Committee) International $<I R>$ Framework [20], the International $<\mathrm{IR}>$ Framework is said to be something totally different. It is not presented as a sustainability report at all, rather, it is a market-led attempt to a different way of thinking about corporate success and reporting [20] (p. 2), [20] (p. 23), [54] (p. 50). Whereas a stated aim of sustainability reports like the GRI is to document how organisations impact natural and social environments, the stated aim of $\langle\mathrm{IR}\rangle$ is to provide a concise description of how organisations create value using six types of capital: financial, intellectual, human, social and relationships, manufactured and natural [68]. However, its intended audience is the providers of financial capital 
only [20] (p. 7). Thus, while $<\mathrm{IR}>$ draws concepts like natural capital from sustainability reporting, $<$ IR $>$ adopts its aim and target-audience from mainstream shareholder primacy corporate reporting [54] (p. 50), [85] (p. 406). As described by the former CEO of the IIRC, 'IR is a market-led response to the corporate reporting challenges of the twenty-first century. Businesses require an evolution in the system for reporting, facilitating, and communicating mega-trends without the complexity and inadequacy of out-of-touch reporting requirements' [39] (p. vi).

\subsubsection{What is $<\mathrm{IR}>$ ?}

Integrated reporting has rapidly gained considerable prominence since the formation of the IIRC and publication of the International $<I R>$ Framework [79] (p. 1043). One of the $<$ IR $>$ Framework's aims is to 'enhance accountability and stewardship for the broad base of capitals (financial, manufactured, intellectual, human, social and relationship (societal), and natural (environmental)) and promote understanding of their interdependencies' [20] (p. 2). The Framework is based on an idea of 'shared value creation' by providers of these 'six capitals' [20] (p. 2). 'Stewardship'-Known in corporate governance notably from 'stewardship codes'-Refers to the responsibility of the organisation to care for, or use responsibly, the capitals that its activities and 'outputs' (products, services, by-products and waste) affect [20] (para. 3.15). As such integrated reporting represents at least on the text level a stakeholder management model already integrated in many corporate governance codes, just broadening the concept of capital providers from the shareholders only to other internal stakeholders providing other capitals to the organisation, by enlarging the goal of capital efficiency and profit maximisation from financial capital only to other five forms of internal capital provisions.

The roots, and at the same time, the problems, of integrated reporting in corporate governance are, however, deeper than in broadening the capital concept in reporting. The integrated report is only the visible part of what is happening below the surface on governance level, described as 'integrated thinking' and 'integrated decision-making' [86] (p. 8). The International $<\mathrm{IR}>$ Framework emphasises the importance of integrated thinking and its relationship to integrated reporting: 'Integrated thinking is the active consideration by an organisation of the relationships between its various operating and functional units and the capitals that the organisation uses or affects' [20] (p. 2).

According to the International $<\mathrm{IR}>$ Framework, at the core of an organisation is its 'business model' [20] (para. 2.23), [87]. The concept of a 'business model' as used in the Framework represents the way how an organisation creates value, comprising all its activities, its relationships with stakeholders and its tangible and intangible assets and liabilities, and finally the board's responsibilities. As for the board, 'corporate governance' and sustaining and developing the company's business model, are essentially the same thing. In the end of the day, it is a question what kind of 'business model' integrated reporting based corporate governance really reflects, and how it possibly varies from shareholder-centred business model. A business model can generally be defined as the organisational and financial 'architecture' of a business' value creation, articulating how a firm converts resources and capabilities into economic value, including implicit assumptions about customers, their needs, and the behaviour of revenues, costs and competitors [88] (p. 173), [89] (p. 43). At the heart of such a business model is a 'value proposition' that is valuable to both a company's customers and other stakeholders who might otherwise be directly or indirectly affected by a company's activities that can be defined for instance as 'a promise on the economic, environmental and social benefits that a firm's offering delivers to customers and society at large, considering both short-term profits and long-term sustainability' [90] (p. 144), [91] (p. 147).

A business model in the International $<\mathrm{IR}>$ Framework conceptualization 'draws on various six capitals as inputs and, through its business activities, converts them to outputs'. The activities and the outputs lead to 'outcomes', the internal and external positive and negative consequences for the capitals because of the activities and outputs in terms of effects on the capitals [20] (para. 2.25). The business model is an organisation's 'system of transforming inputs, through its business activities, into outputs and outcomes that aims to fulfil the organisation's strategic purposes and create value 
over the short, medium and long term' [20] (para. 4.11). In other words, the business model concept involves (1) the organisation's governance, (2) its enterprise risk management (ERM), and (3) its strategy in the short, medium, and long term, and (4) its internal controls. The business model impacts on these four aspects, while the organisation produces a commodity. The commodity in turn impacts on those four aspects [92] (p. 49). As the $<$ IR $>$ aims to combine key financial as well as non-financial aspects in one report, and based upon those 'six capitals', it is intended to show the reciprocal effects between different performance indicators. The capitals, their interrelatedness and their dependencies must be handled according to integrated thinking, the organisation's long-term strategy, value creation, performance management and management decision and control, all based on integrated thinking [93].

The key to the $<\mathrm{IR}>$ business model concept is the value creation. The $<\mathrm{IR}>$ concept of value creation has changed over time: the original sustainability focus has evaporated while the providers of financial capital ('investment supply chain' [71] (p. 496)) became the targeted users of $<\mathrm{IR}>$. The primary purpose of an $<\mathrm{IR}>$ is after the transition from stakeholder model to financial capital provider model to explain to (only) the providers of financial capital how an organisation creates (them) value over time [20] (para. 1.7, pp. 2, 4), to enable financial capital providers to a more efficient and productive allocation of capital [20] (p. 2). Based on this statement it is fair to conclude that $<$ IR $>$ follows a value concept that is embossed by shareholder value [94] (p. 41). This investor focus makes the $<\mathrm{IR}>$ special; where the primary audience of business model frameworks is almost exclusively management, $<\mathrm{IR}>$ 's primarily audience is providers of financial capital. $<\mathrm{IR}>$ is atypical in using the business model to communicate externally, rather than primarily as an internal mechanism to focus management's attention on how the business either realises value or innovates [85] (p. 412).

The $<\mathrm{IR}>$ value concept has two interrelated aspects; value created for (1) the organisation itself, which enables financial returns to the providers of financial capital, and for (2) others, that is, stakeholders and society at large [20] (para. 2.4). The value concept expresses a 'fact' (that is in legal terms of course false) 'that in legal terms the organization belongs to and is primarily governed by the financial capital providers' [94] (p. 44). Due to this investor-centered value concept, investors (the providers of financial capital) are (emphasis here) 'interested in the value an organization creates for itself. They are also interested in the value an organisation creates for others when it affects the ability of the organisation to create value for itself, or relates to a stated objective of the organisation (e.g., an explicit social purpose) that affects their assessments' [20] (para. 2.5). The value to others is accordingly subordinated to investor value, and the others have value only through it unless otherwise stipulated in the organisation's by-laws. So, as a default, the others have only an instrumental value to the investors.

With this backdrop, the purpose of $<\mathrm{IR}>$ is to take into consideration the financial impact of non-financial issues and through that to improve the comprehensiveness of corporate reporting for the shareholder [95] (p. 95), [96]. For this reason, an increase, or a decrease in other capitals than financial capital is irrelevant, unless it is material to the organisation's ability to generate returns to providers of financial capital. 'This includes taking account of the extent to which effects on the [other] capitals have been externalized (i.e., the costs or other effects on capitals that are not owned by the organization)' [20] (para. 2.7). 'Externalities may be positive or negative (i.e., they may result in a net increase or decrease to the value embodied in the capitals). Externalities may ultimately increase or decrease value created for the organisation; therefore, providers of financial capital need information about material externalities to assess their effects and allocate resources accordingly' [20] (para. 2.8). The investor-centrism of the $<\mathrm{IR}>$ business model reflects, however, not only the role of the providers of capital but also sets obligations for the boards and management for 'integrated thinking' (see below) on how different capitals connect for the benefit of the providers of financial capital [85] (p. 412). This 'integrated thinking' logic suggests that business models should enable managers to re-conceptualise or re-focus their organisations' 'value creating activities' and through that, to review their business' key performance indicators (KPIs) or strategies more holistically [85] (p. 414). 
The nature of $<\mathrm{IR}>$ can be understood through the way how it treats humans and nature $[97,98]$. The International $<\mathrm{IR}>$ Framework makes a difference between intellectual capital, human and social and relationships capital. 'Intellectual capital' is organisational, knowledge-based intangibles including 'intellectual property such as patents, copyrights, software right sand licences', 'organisational capital' such as 'tacit knowledge, systems, procedures, and protocols' [20] (p. 12). 'Human capital' entails people's competencies, capabilities, and experience. Human capital, as all the other capitals except financial capital, is viewed exclusively from the company's and so its institutional investors' viewpoint: humans have no intrinsic value as their value depends on the contribution they make towards corporate success. Humans who are not inputs to the business model have no value.

'Social and relationships capital' is the 'institutions and the relationship with and between communities, groups of stakeholders and other networks, and the ability to share information to enhance individual and collective well-being' [20] (p. 12). 'Natural capital' is 'all renewable and non-renewable environmental resources and processes that provide goods or services that support the past, current or future prosperity of an organisation. It includes air, water, land, minerals and forests, biodiversity and eco-system health' (emphasis added) [20] (p. 12, para. 2.15), [10] (p. 88), [98]. The essential phrase here is the 'prosperity of an organisation'; the International $<\mathrm{IR}>$ Framework is interested only in those elements of the natural capital that are utilized by an organisation [98]. It notes that 'many organizations rely on raw materials to ensure production continuity. Eco-system services such as water purification. may also feature prominently in the business model. It is important to explain how secure the availability, quality and affordability of these components of natural capital are' [20] (para. 2.28). All in all, $<\mathrm{IR}>$ 'tells a firm's value creation narrative going forward, by specifically referring to corporate strategy, how the strategy translates into a firm's business model and how the business model takes advantage of the six forms of capital to create or destroy value. "Integrated thinking" is meant to facilitate high-quality IR by promoting a long-term outlook' [99] (p. 939). As mentioned above, the International $<\mathrm{IR}>$ Framework emphasises the importance of integrated thinking within the organisation: 'Integrated thinking is active consideration by an organization of the relationships between its various operating and functional units and the capitals that the organisation uses or affects. Integrated thinking leads to integrated decision-making and actions that consider the creation of value over the short, medium and long term' [20] (p. 2).

Integrated thinking has two components [100] (pp. 577-578). The first connects strategy, governance, past performance, and prospects through which an organisation considers the connectivity and interdependencies between the factors that have a material effect on Ibility to create value over time. These include the capacity of the organisation's governance structure to respond to stakeholder needs, interests and expectations as well as the capitals it uses, and affects, and the critical interdependencies, including trade-offs, between them [20] (p. 9).

The second aspect of integrated thinking connects the organisation's various internal departments. The process of producing an integrated report explores the relationships between a company's various internal units to provide a deeper and better understanding of its internal processes and relationships [100] (pp. 577-578). Integrated thinking takes into account the connectivity and interdependencies between the capitals and critical interdependencies between them, the capacity of the organisation to respond to key stakeholders' legitimate needs and interests, how the organisation tailors its business model and strategy to respond to its external environment and the risks and opportunities it faces, the organisation's activities, financial and other performance and outcomes in terms of the capitals-Past, present and future [20] (p. 2).

\subsubsection{Use of Integrated Reporting in Corporate Governance}

The role of integrated thinking to understand an organisation's business model in integrated reporting can be understood when we consider the role of corporate reporting in corporate governance. According to the Cadbury Committee (1992) classical definition, corporate governance is 'the system by which companies are directed and controlled' [101] (para. 2.5), [102] (p. 3). In the Cadbury Report 
and in other mainstream corporate governance codes, a 'system' refers, however, only to the 'financial aspects of corporate governance' [101] (para. 2.6), that is, shareholder value and emphasis on the board's and the management's accountability to providers of financial capital [101] (para. 3.4), or as put in the Report itself, effective accountability 'is the essence of any system of good corporate governance' [101] (para. 1.1), [103] (p. 122) and 'issue for corporate governance is how to strengthen the accountability of boards of directors to shareholders' [101] (para. 6.1), [103] (p. 118).

The Cadbury Committee itself was tasked firstly simply to deal with the financial aspects of corporate governance. One crucial reason for the Cadbury Report was flaws in the quality of corporate reporting [104] (p. 421). According to the Report itself, the code was motivated by 'the perceived low level of confidence both in financial reporting and in the ability of auditors to provide the safeguards which the users of company reports sought and expected. The underlying factors were seen as the looseness of accounting standards, the absence of a clear framework for ensuring that directors kept under review the controls in their business, and competitive pressures both on companies and on auditors which made it difficult for auditors to stand up to demanding boards' [101] (para. 2.1).

After the Cadbury Committee, the scope of corporate governance codes has expanded considerably [102]. In the 1990's it was thought that the globalisation of financial systems causes a convergence of corporate governance systems towards the Anglo-American model because it was based on stock market principles [105]. Increasing demands for corporate responsibility have, however, lead to an emerging trend towards a more stakeholder-orientated view of the corporation also in Anglo-American countries, certainly in the United Kingdom and Australia [106] (p. 149). Finally, the South African 'King thinking' is based on the idea that the modern approach of management is one of an integrated thinking [107] (p. 256). The South African model of integrated thinking-based management considers all six capitals the organisations uses, transforms and provides. An integrated report is just the outcome of integrated thinking; according to the latest King IV Report, '[i]ntegrated thinking is defined as the active consideration by an organization of the relationships between its various operating and functional units and the capitals that the organization uses or affects' [84] (p. 13).

The integrated thinking in the Framework and the King reports can be compared with the idea of 'integrated governance', proposed for instance by the United Nations Environment Programme Finance Initiative (UNEP FI) [108]. Unlike integrated thinking, integrated governance is purported as a model that 'moves sustainability issues from the periphery of corporate strategy to the heart of it' [108] (p. 5), or to move from 'governance for sustainability' to an integrated governance perspective [108] (p. 35). Integrated governance tries to answer the question 'If current governance practices are ineffective in promoting a culture of sustainability, then what is the alternative?' [108] (p. 35). In integrated governance, sustainability issues are integrated in a way that ensures value creation for the company and beneficial results for all stakeholders in the long term, to ensure the management of all types of capital [108] (p. 35). Integrated governance requires oversight of a sustainable strategy by the board so that sustainability risks and opportunities are seamlessly part of the strategic agenda for the firms, and integrated reporting is used as the means to measure progress in both financial and non-financial targets [108] (p. 36).

More than reporting is, however, required to establish a true integrated governance. Considering integrated thinking as a basis for integrated governance, it is true that integrated thinking requires a business to reconsider the short, medium- and long-term sustainability of the entity [107] (p. 257). In $<$ IR $>$ it would require that the firm should report on all the capitals that are affected by its activities [97] (p. 6), $[37,109,110]$. The $<\mathrm{IR}>$ Framework does the opposite, as capitals are reported only if they provide value to the firm and its providers of financial capital. If the firm causes externalities, decreasing the value of the 'capitals' outside the organisation, they are not reported. Accordingly, the Framework excludes damage caused by the firm to capitals (for instance to ecosystem, infrastructure and people through pollution emitted) if the damage does not affect the firm's production process (infrastructure, raw materials and people in the firm's service) [97] (pp. 6-7). The Framework accepts 
that the integrated report should cover the impact of the capitals on the firm but ignores the firm's impact (causing externalities) on these capitals.

The problem of the $<\mathrm{IR}>$ Framework is accordingly that it does not follow integrated thinking in the end. As all kinds of 'CSR' and 'sustainability' reports are targeted to the classical 'stakeholders', the $<\mathrm{IR}>$ addresses (institutional) investors both in equity and debt ('investment supply chain' [85] (p. 496)), 'providers of financial capital to enable a more efficient and productive allocation of capital' [20] (p. 2). As stated in the Framework itself, the 'primary purpose of an integrated report is to explain to providers of financial capital how an organisation creates value over time. It therefore contains relevant information, both financial and other' (emphasis added) [20] (para. 1.7). An integrated report only 'benefits all stakeholders interested in an organization's ability to create value over time, including employees, customers, suppliers, business partners, local communities, legislators, regulators and policy-makers' [20] (para. 1.8).

The aim of $<\mathrm{IR}>$ is to get managers and providers of financial capital to consider the long-term consequences of a broader set of capitals [99] (p. 939). The investor-centrism of $<\mathrm{IR}>$ helps the board and the management to avoid a conflict of objectives arising from the consideration of heterogeneous target groups [31] (p. 278). On the other hand, $<\mathrm{IR}>$ is focused on helping investors identify those social and environmental issues that are material from an investor's perspective, and creating the 'business case' for the consideration of ESG issues, which it believes will cause managers within the corporation to take these issues more seriously and then seek to improve performance [33] (p. 131).

Using Humphrey's, O'Dwyer's and Unerman's expression, the target group was the 'long-term enlightened investor' and so, the 'enlightened shareholder' logic prevails [111] (pp. 53, 44). As investors decide on an entity's business model, and the strategies and decisions taken, because they appoint and dismiss the board and 'decide on the provision of cash, which is the "fuel" that is needed to keep the entity running'. Through this decisive power position investors have a key role for the value concept applied in the the board's and the management's strategies and decisions, whether it includes just one sort of capital or whether it is more comprehensive [94] (p. 51-52). In this form, $<$ IR $>$ sits well in modern shareholder primacy corporate governance.

The most relevant usage of integrated reporting in corporate governance is the South African corporate governance codes, the King reports. In the South African 'King tradition', considerations of sustainability are 'at the heart of the leadership and governance role of the board' [112], connecting sustainability to the Brundtland Report definition ('meeting the needs of the present generation without compromising the ability of future generations to meet their needs') [113] (p. 15), the UN Sustainable Development Goals and the 'six capitals' of the IIRC. The King tradition connected integrated reporting to the South African Constitution imposing responsibilities upon individuals and juristic persons for the realisation of the most fundamental rights [114] (p. 10), reflecting the uniquely African form of communitarianism embodied in the concept of 'Ubuntu' [114] (p. 61). Companies were citizens of the South African community with a consequent ethical responsibility to disclose their impacts on 'other' South African citizens [53] (p. 54).

The King tradition' view of governance differs drastically from that of the IIRC's. Albeit according to one of the Guiding Principles of the International $<\mathrm{IR}>$ Framework an $<\mathrm{IR}>$ 'should provide insight into the nature and quality of the organization's relationships with its key stakeholders, including how and to what extent the organization understands, takes into account and responds to their legitimate needs and interests' [20] (p. 5), the Framework requires each organisation to explain how its 'governance structure support[s] its ability to create value in the short, medium and long term', viewing governance as a cog in the value-creation process [20] (p. 25), [53] (p. 55). By contrast, the King tradition defined governance as about values (i.e., ethics) rather than value-creation: 'Good governance is essentially about effective leadership. Leaders should rise to the challenges of modern governance. Such leadership is characterized by the ethical values of responsibility, accountability, fairness and transparency' [114] (p. 9), [53] (p. 55). The practical implication of these principles is that changes in non-financial capital that impact stakeholders may be material to IR even if they have no 
long-term effect on financial capital. For instance, if safety at work is a fundamental right, then it is ipso facto material irrespective of its impact on financial value [53] (p. 54). The King tradition has taken integrated thinking seriously: enhancing all forms of capital represented the creation of value and depleting them constituted destruction of value [112].

The most recent King IV Report uses both the six capitals model and reference an integrated economic, social and environmental context within which corporations operate as lenses through which to view sustainable development, to expand their view of success and redefine it in terms of long-term, positive outcomes for business, society and the environment. According to King IV, an organisation is a part of society in its own right [84] (p. 4). It does not exist in its own narrow universe of internal stakeholders within its value chain. In King IV there is a focus on reporting in an integrated manner across the dimensions of the economy, society, and the natural environment and on disclosure as essential for market and societal accountability mechanisms to operate [112]. Indeed, the focus in King IV is not anymore on the integrated reporting itself but in integrated thinking. Many in South Africa believe that adopting integrated thinking throughout the business is more critical than preparing the annual integrated report. [115]. Investors look for integrated thinking in the companies they invest in; it shows that the board and management are aware of all the capitals needed to ensure the ongoing viability of the business. The board will set or approve the company's strategic objectives only after considering all the capitals important to the viability of the business. Board and management will implement these objectives throughout the company and ensure that the staff recognise their importance [115] (p. 12).

Albeit the King IV Report references the International $<$ IR $>$ Framework underpinned by the same thinking and terminology [116], it is not an integral part of the Report. As before, there is not a requirement to use of the Framework. The Integrated Reporting Committee of South Africa [117] has only endorsed the $<\mathrm{IR}>$ as 'good practice on how to prepare an integrated report' but it is the substance of the report - referred to in King IV Report as an 'outcomes-based approach'-That is important, not its form [84] (p. 7). The outcomes-based approach determines that companies in South Africa may prepare an integrated report in any form they choose as long as they demonstrate compliance with all of the King IV governance principles on an 'apply and explain basis, and this does not explicitly demand or necessitate the $<$ IR $>$ [118].

Another example using integrated reporting as part of its corporate governance code is Malaysia. According to the revised Malaysian Code of Corporate Governance, [119] large companies [120] are encouraged to adopt integrated reporting based on a globally recognised framework [119] (p. 45, Practice para. 11.2.), [121]. As stated in the Code, an 'integrated report is the main report from which all other detailed information flows, such as annual financial statements, governance and sustainability reports. It is concise communication about how a company's strategy, performance, governance, and prospects lead to value creation. An integrated report improves the quality of information available to investors and promotes greater transparency and accountability on the part of the company. The preparation of this report requires integrated thinking of the relationship between its various operating and functional units, thus breaking down internal silos and reducing duplication' [119] (p. 46, Guidance para. 11.2).

Unlike in South African King Code, the reference in the Malaysian Code is directly to the International $<\mathrm{IR}>$ Framework $[82,119,122]$. However, the use of integrated reporting is only encouraged, and does accordingly not fall under the Code's 'apply or explain' [119] (p. 8, para. 5.2) requirement. Implementation of integrated reporting is still low, 5 percent of top 100 companies by revenue in Malaysia in 2017 [123,124] (p. 36), [125,126] (p. 106), [81] (p. 184). If International <IR> Framework is to be implemented efficiently, then it should be driven by regulation, being either fully mandatory or on an 'apply or explain' basis [126] (p. 108), [81] (p. 199). 


\subsubsection{Why Integrated Reporting Is Also Failing}

The problems $<\mathrm{IR}>$ are to solve in financial reporting are real: (1) complexity, (2) lack of connectivity, and (2) lack of forward-looking information [127] (p. 60). In the last few decades, financial reporting has become steadily more complex and financial reports longer. New and extensive reporting requirements and more and more complex financial reporting standards such as the IFRS have caused information overload, making it increasingly difficult for users to extract the relevant information they need. It is also clear there is not enough 'non-financial' (sustainability) information in traditional reports, and if there is, it is not adequately linked with the financial information. Statutory financial statements, management commentaries, corporate governance reports and 'corporate social responsibility' and 'sustainability' reports form isolated parts within annual reporting or even published separately. Finally, traditional corporate reporting lacks forward-looking information and provides limited usefulness in predicting the long-term performance of an organisation.

The International Integrated Reporting Council expresses as its 'long term vision a world in which integrated thinking is embedded within mainstream business practice in the public and private sectors, facilitated by Integrated Reporting $(<\mathrm{IR}>)$ as the corporate reporting norm. The cycle of integrated thinking and reporting, resulting in efficient and productive capital allocation, will act as a force for financial stability and sustainability' [20] (p. 2). However, there is only one reference to sustainability in the $<\mathrm{IR}>$ Framework itself, which is to a separate sustainability report that is not part of the integrated report [20] (para. 1.13). Indeed, it is not the Framework's purpose at all to address sustainability $[38,80]$ (p. 8), [51] (p. 20).

That sustainability is ignored in the $<\mathrm{IR}>$ Framework is not a surprise, as the Framework makes clear that the principal function of integrated reporting is the reporting of 'value' to the financial investors; as stated in the Framework, the 'primary purpose of an integrated report to explain to providers of financial capital how an organization creates value over time' [20] (para. 1.7), not value to the environment and society, or not even to 'stakeholders', nor 'present and future generations'. The primary purpose of an integrated report is to explain the firm's value creation to financial investors and hence 'value' must be interpreted according to their interests [97] (p. 5). As stated in the Framework, financial investors 'are interested in the value an organisation creates for itself. They are also interested in the value an organization creates for others when it affects the ability of the organization to create value for itself' (emphasis added) [20] (para. 2.5). Taking to consideration the purpose of the Framework, 'value for itself' should be interpreted as 'value for investors' [97] (p. 6). The Framework accepts that providers of financial capital are principally interested in the benefits that they can expect from the firm, referring in specifically to 'financial returns to the providers of financial capital' [20] (para. 2.4). From a firm's viewpoint, other capitals than financial capital have value only in so far as they contribute to the firm's value. The Framework's investor orientation essentially determines the content of the integrated report [97] (p. 6).

This is reflected in practice. According to an empirical research by Ahmed Haji and Hossain in South Africa, companies follow more and more the 'multiple capital framework' language with cursory use of specific $<\mathrm{IR}>$ terms, recognising that the multiple capitals are increased, decreased and/or transformed through organisational activities, and that there are potential trade-offs between multiple capitals, or components of a capital [128] (p. 349). In this sense, the $<$ IR $>$ has reached weak sustainability level. The content of the reported information is generic, often vague, and lacks contextual meaning and substance. The discussions on multiple capitals are largely limited to integrated reports, with companies hardly making references to the interdependencies and trade-offs between the capitals in other organisational reporting channels. The adoption of the $<\mathrm{IR}>$ does, in other words, not necessarily mean adoption of 'integrated thinking'. Companies use in their reports without constraints rhetorical language to exaggerate positive outcomes while underplaying, even dismissing, negative comparisons and trends [128] (p. 439). 


\subsubsection{Conclusion}

So, what kind of stakeholder model, if any, does integrated reporting and especially International $<\mathrm{IR}>$ Framework represent? The answer is that it is not a step forward in sustainability but vice versa, it reflects an 'enlightened' version of shareholder primacy, not even any stakeholder model, and far from any sustainability model. The Framework is investor oriented and the role of the stakeholders, as providers of non-financial capitals, are seen through the value their capitals generate to the providers of financial capital. There is accordingly a clear resemblance between the $<\mathrm{IR}>$ Framework and section 172 of the UK Companies Act 2006 [30]. According to section 172 company directors are required 'to promote the success of the company for the benefit of its members [shareholders] as a whole' while the Framework's objective is that a firm should maximize its long-term value, value being interpreted as 'value for itself' [97] (p. 9). Section 172 lists a number of factors that directors should have regard to in promoting the company's success, including the long term consequences of their decisions, the interests of employees, the need to foster the company's business relationships with suppliers, customers and others, the impact on the community and the environment and the need to maintain a reputation for high standards of business conduct, all mentioned as important also in the Framework, as contributing to the long term success of the organisation. Both the Framework and the Companies Act adopt the same approach: the firm should maximize long-term value for shareholders, and, to achieve this, it should have proper regard for the interest of others [97] (p. 9).

As is section 172 of the Companies Act, the Framework as a safeguard of environmental and social interests is illusory. Both prioritise financial investors' interests over stakeholders' interests. Additionally, the mode of regulation in either of the frameworks do not provide substantive content to integrated thinking with the visibility that is necessary for it to be functionally a viable way of stakeholders' featuring in corporate decision-making as a matter of best practice [30]. As does section 172 of the Companies Act, also the Framework gives the illusion that something is being done to acknowledge stakeholders' interests in corporate decision-making.

What is then the impact, if any, of integrated reporting to material corporate governance in the codes it is included in? The unfortunate conclusion is that the integrated thinking behind integrated reporting strengthens the shareholder primacy ideology behind the codes more than weakens it. However, the South African King IV Code and its unique conception of integrated thinking is an exception and brings hope to those seeing integrated thinking and reporting as a path to sustainable governance. So far, when thinking the Framework as a whole, the integrated view and especially the 'integrated thinking' behind International $<\mathrm{IR}>$ Framework does represent a genuine sustainable value creation driven business model based on the boundaries of the planet and social foundation for humanity. Rather it is merely a view to encourage organisations to take care of the profits of the specific capital providers.

The most important question is, however, what the future path of the $<\mathrm{IR}>$ Framework is [80] (pp. 8, 14-15). Firstly, the key is in integrated thinking itself. Genuine sustainable change depends on the extent to which integrated thinking can confront, challenge and colonise the 'unintegrated thinking' that dominates contemporary business governing [109] (p. 21). It is also crucial for a revised thinking in shareholder primacy based corporate governance codes, referring more to integrated thinking and reporting. Investors are crucial in integrated thinking both by appointing managers that are willing and able to apply integrated thinking and applying integrated thinking themselves in their capital allocation decisions, not forgetting, however, all other participants in investment supply chains and market institutions, such as stock exchanges [94] (p. 52). The concept of $<\mathrm{IR}>$ alone is not intended to and cannot faciliatet change in thinking in the investment supply chain itself. However, integrated thinking has potential to be an important piece in corporate sustainability. In this respect and in this respect alone, the IIRC is right in expressing its expectation that 'the cycle of integrated thinking and reporting, resulting in efficient and productive capital allocation, will act as a force for financial stability and sustainability' [94] (p. 51), [20] (p. 2). 
Nevertheless, $<\mathrm{IR}>$ might develop as a key information instrument for all stakeholders, not only for shareholders, and might replace CSR reporting in the long run. The strength of $<\mathrm{IR}>$ is that it focuses on value creation through the lens of the six capitals rather than on environmental and social impacts through the lens of stakeholder materiality as the CSR or sustainability reporting does [85] (p. 490). <IR > 'draws on different reporting strands and communicates the full range of factors that materially affect the ability of an organization to create value over time', enhancing 'accountability and stewardship for the broad base of capitals and promote understanding of their interdependencies' [20] (p. 2). Yet, it is seen as a preserver of status quo; it is seen as storytelling and meeting institutional expectations, not to encourage innovations in reporting processes nor change to corporate norms $[99,129]$ (p. 943).

Secondly, with focus on capitals and business models, there is no need to concentrate on 'stakeholders'. One 'stakeholder' can have an impact on different capitals [130] (p. 9). The same person can simultaneously be the customer, employee, and shareholder of the same company and, in such a context, a simplistic stakeholder-based classification become less relevant [130] (p. 17).

Thirdly, the clear benefit of $<\mathrm{IR}>$ is in its business model innovation [131] (p. 88). The danger is, however, that the business model concept remains as marketing information only [131] (p. 89). An even bigger danger is that it is more an obstacle than driver for corporate governance reforms. In the end of the day the question is, is $<\mathrm{IR}>$ too deeply rooted in the business case for sustainability to make a sustainability case for business? [109] (p. 21).

\section{The European Reporting Framework}

\subsection{European Financial Reporting Framework}

As said, the backbone of European reporting regulation is the Accounting Directive of 2013, setting rules for preparing annual financial statements and consolidated financial statements, management reports, reports on payments to governments, corporate governance statements and 'non-financial' statements.

The harmonisation of European accounting law started in 1978 with the Fourth Company Law Directive on annual accounts [132], continuing in 1983 with the Seventh Company Law Directive on consolidated accounts [133]. These directives were replaced in 2013 by the Accounting Directive [4]. The Fourth and Seventh Company Law Directives did not only apply to listed companies incorporated in the EU only, but also to all other types of companies referred to in those directives, including (other) public and private companies with limited liability.

In the mid-1990's, however, the European legislator became increasingly interested in adopting substantive requirements on consolidated annual accounts applicable exclusively to listed companies. One of the explanations was the increased relevance of the international capital market for listed companies based in the European Member States as a source of financing of business activities. A new line was taken in further harmonisation of the reporting rules for European listed companies by linking up them to international reporting standards [134]. In 2000 the European Commission announced the implementation of an 'endorsement' mechanism, on which basis the European Commission could 'adopt' the standards issued by the IASB [135]. In early 2001 the proposal for an IAS Regulation followed, which included this mechanism [136]. The Regulation was subsequently adopted in July 2002 [5]. After that, the IFRS has dominated the European financial reporting scene [137].

Besides rules on financial statements and consolidated financial statements, the Accounting Directive includes rules on management reports (Article 19), non-financial statements (Article 19a), corporate governance statement (Article 20), consolidated management reports (Article 29), auditing (Article 34) and reports on payments to government (Chapter 10, Articles 41-48). Additionally, the Commission has proposed rules on reports on income taxes paid (Chapter 10a). 


\subsection{Management Reports}

Management report. In Article 19 of the Accounting Directive there are detailed rules of the contents of the management report. Member States may exempt small and medium-sized undertakings from the obligation to prepare management reports with certain exceptions.

As a principal rule, the management report shall include a fair review of the development and performance of the undertaking's business and of its position, together with a description of the principal risks and uncertainties that it faces, with a balanced and comprehensive analysis of the development and performance of the undertaking's business and of its position, consistent with the size and complexity of the business. 'To the extent necessary' for an understanding of the undertaking's development, performance or position, the analysis shall include both financial and, where appropriate, non-financial key performance indicators (KPI's) relevant to the particular business, including information relating to environmental and employee matters. In providing the analysis, the management report shall, 'where appropriate', include references to, and additional explanations of, amounts reported in the annual financial statements.

The management report shall also give an indication for instance of the undertaking's likely future development and activities in the field of research and development, in relation to the undertaking's use of financial instruments and where material for the assessment of its assets, liabilities, financial position and profit or loss, the undertaking's financial risk management objectives and policies, including its policy for hedging each major type of forecasted transaction for which hedge accounting is used, and the undertaking's exposure to price risk, credit risk, liquidity risk and cash flow risk.

Consolidated management report. Article 29 of the Accounting Directive includes provisions on a consolidated management report. The report shall as a minimum, in addition to any other information required under other provisions of the Directive, set out the information required by Articles 19 and 20, taking account of the essential adjustments resulting from the particular characteristics of a consolidated management report as compared to a management report in a way which facilitates the assessment of the position of the undertakings included in the consolidation taken as a whole. Article 29 includes provisions on specific adjustments. If a consolidated management report is required in addition to the management report, the two reports may be presented as a single report.

Corporate governance statement. According to Article 20 of the Accounting Directive undertakings governed by the law of a Member State and whose transferable securities are admitted to trading on a regulated market of any Member State shall include a corporate governance statement in their management report. Member States may permit the information to be set out in a separate report published together with the management report or a document publicly available on the undertaking's website, to which reference is made in the management report. Member States may exempt undertakings specified in the Article from certain provisions in the Article.

The statement shall be included as a specific section of the management report and shall contain at least the minimum information specified in the Article, for instance a reference to the corporate governance code to which the undertaking is subject or the undertaking may have voluntarily decided to apply as well as all relevant information about the corporate governance practices applied over and above the requirements of national law. If the undertaking, in accordance with national law, departs from a corporate governance code partly or in a whole, an explanation must to be made as to which parts of the corporate governance code it departs from and the reasons for doing so ('comply or explain').

Additionally, the statement must include a description of the main features of the undertaking's internal control and risk management systems in relation to the financial reporting process, a description of the operation of the shareholder meeting and its key powers and a description of shareholders' rights and how they can be exercised and the composition and operation of the administrative, management and supervisory bodies and their committees. The statement must also include a description of the diversity policy applied in relation to the undertaking's administrative, management and supervisory bodies with regard to aspects such as, for instance, age, gender, or educational and professional 
backgrounds, the objectives of that diversity policy, how it has been implemented and the results in the reporting period. If no such policy is applied, the statement shall contain an explanation as to why this is the case.

'Country-by-country report'. Chapter 10 of the Accounting Directive includes provisions on a report on payments to governments and its publication. According to Article 42, Member States shall require large undertakings and all public-interest entities active in the extractive industry or the logging of primary forests to prepare and make public a report on payments made to governments on an annual basis. That obligation shall not apply to any undertaking governed by the law of a Member State which is a subsidiary or parent undertaking, where both of the following conditions are fulfilled: (a) the parent undertaking is subject to the laws of a Member State; and (b) the payments to governments made by the undertaking are included in the consolidated report on payments to governments drawn up by that parent undertaking in accordance with Article 44 on consolidated report on payments to governments. Article 41 includes definitions of an 'undertaking active in the extractive industry', 'undertaking active in the logging of primary forest', 'government' and 'payment'. Article 43 includes detailed rules on disclosure of the payments to governments.

Commission review. According to Article 48 the Commission shall review and report on the implementation and effectiveness of this Chapter, as regards the scope of, and compliance with, the reporting obligations and the modalities of the reporting on a project basis. It shall be completed by 21 July 2018. The report shall be submitted to the European Parliament and to the Council, together with a legislative proposal, if appropriate. That report shall consider for instance the extension of the reporting requirements to additional industry sectors and whether the report on payments to governments should be audited. The Commission published in November 2018 a study reviewing the country-by-country reporting done by the extractive and logging industries, its implementation, effectiveness, and impacts [138]. The report has not been published yet.

Country-by-country report on income taxes paid. Additionally the European Commission proposed in April 2016, in order to implement in the Union Action 13 of the OECD Action Plan endorsed by the G20 to fight base erosion and profit shifting (BEPS) requiring a country-by-country report from multinational enterprises (MNEs) on income tax paid, a new Chapter 10a to the Accounting Directive requiring that MNEs disclose publicly in a specific report the income tax they pay together with other relevant tax-related information. MNEs, whether headquartered in the EU or outside, with turnover of more than EUR 750m would need to comply with these additional transparency requirements. For the first time, not only European businesses but also non-European multinational companies doing business in Europe would have the same reporting obligations [139]. Albeit adopted by the European Parliament in March 2019, the proposal is still in the Council, and it has not entered the trilogue phase [140]. The Parliament has called on both the Council presidencies and the Member States to break the deadlock within the Council but without avail.

When adopting the proposal in June 2017, the Parliament added to the information to be provided and to be published, details of public subsidies received and any donations made to politicians, political organisations or political foundations and whether undertakings, subsidiaries or branches benefit from preferential tax treatment, from a patent box or equivalent regimes. The report on income tax information would be published in a common template laid down by a Commission delegated act [141]. The template could be a very simplified exercise, requiring an explanation if for example the undertaking has benefited from preferential tax treatments or other positive treatments.

Transparency Directive. According to Article 6 of the Transparency Directive [142] Member States shall require issuers active in the extractive or logging of primary forest industries, as defined in Article 41 of the Accounting Directive, to prepare on an annual basis, in accordance with Chapter 10 of that Directive, a report on payments made to governments. The report shall be made public at the latest six months after the end of each financial year and shall remain publicly available for at least 10 years. Payments to governments shall be reported at consolidated level. 


\section{3. 'Non-Financial' Statements}

Non-financial statement. According to Article 19a of the Accounting Directive large undertakings which are public-interest entities exceeding on their balance sheet dates the criterion of the average number of 500 employees during the financial year shall include in the management report a non-financial statement containing information to the extent necessary for an understanding of the undertaking's development, performance, position and impact of its activity, relating to, as a minimum, environmental, social and employee matters, respect for human rights, anti-corruption and bribery matters. The statement should include a brief description of the undertaking's business model, a description of the policies pursued by the undertaking in relation to those matters, including due diligence processes implemented, the outcome of those policies, the principal risks related to those matters linked to the undertaking's operations including, where relevant and proportionate, its business relationships, products or services which are likely to cause adverse impacts in those areas, and how the undertaking manages those risks, non-financial KPIs relevant to the particular business.

Consolidated non-financial statement. Article 29a includes provisions of consolidated non-financial statements for public-interest entities which are parent undertakings of a large group exceeding on its balance sheet dates, on a consolidated basis, the criterion of the average number of 500 employees during the financial year. Provisions are identical to those in Article 19a.

Separate report. Member States shall provide that undertakings may rely on national, Union-based, or international frameworks, and if they do so, undertakings shall specify which frameworks they have relied upon. According to Recital 9 of Non-Financial Reporting Directive [32], in providing this information, undertakings which are subject to this Directive may rely on national frameworks, Union-based frameworks such as the Eco-Management and Audit Scheme (EMAS), or international frameworks such as the United Nations (UN) Global Compact, the Guiding Principles on Business and Human Rights implementing the UN 'Protect, Respect and Remedy' Framework, the Organisation for Economic Co-operation and Development (OECD) Guidelines for Multinational Enterprises, the International Organisation for Standardisation's ISO 26,000, the International Labour Organisation's Tripartite Declaration of principles concerning multinational enterprises and social policy, the Global Reporting Initiative, or other recognised international frameworks. According to the Commission Guidelines, companies may also consider using other reporting frameworks, such as those mentioned in the introduction to these guidelines [40].

An undertaking which is a subsidiary undertaking is exempted from the obligation set out in Article 19a if that undertaking and its subsidiary undertakings are included in the consolidated management report or the separate report of another undertaking, drawn up in accordance with Article 29 and Article 19a.

Commission Guidelines. The rules in Article 19a are complemented by the Commission non-binding Guidelines (2017) on methodology for reporting non-financial information [40]. The flexibility of Article 19a, stating that Member States shall provide that undertakings may rely on national, Union-based or international frameworks, and if they do so, undertakings shall specify which frameworks they have relied upon, is described in a list set in the Guidelines:

- $\quad$ CDP (formerly the Carbon Disclosure Project).

- the Climate Disclosure Standards Board.

- the OECD Due Diligence Guidance for Responsible Supply Chains from Conflict-Affected and High-Risk areas, and the supplements to it.

- the Eco-Management and Audit Scheme (EMAS) and the related Sectoral Reference Documents.

- the European Federation of Financial Analysts Societies' KPIs for Environmental, Social, Governance (ESG), a Guideline for the Integration of ESG into Financial Analysis and Corporate Valuation.

- Global Reporting Initiative.

- Guidance for Responsible Agricultural Supply Chains of FAO-OECD. 
- Guidance on the Strategic Report of the UK Financial Reporting Council.

- Guidelines for Multinational Enterprises of the Organisation for Economic Cooperation and Development.

- Guiding Principles Reporting Framework on Business and Human Rights.

- ISO 26,000 of the International Organisation for Standardisation.

- the International Integrated Reporting Framework.

- Model Guidance on reporting ESG information to investors of the UN Sustainable Stock Exchanges Initiative.

- the Natural Capital Protocol.

- Product and Organisation Environmental Footprint Guides.

- the Sustainability Accounting Standards Board.

- the Sustainability Code of the German Council for Sustainable Development.

- the Tripartite Declaration of principles concerning multinational enterprises and social policy of the International Labour Organization.

- the United Nations (UN) Global Compact.

- UN Sustainable Development Goals, Resolution of 25 September 2015 transforming our world: the 2030 Agenda for Sustainable Development.

- UN Guiding Principles on Business and Human Rights implementing the UN 'Protect, Respect and Remedy' Framework [40] (pp. 3-4).

Criticism. The problems of the Non-Financial Reporting Directive are evidenced by a 2019 study of the Alliance for Corporate Transparency [143], assessing how 1000 European companies disclose information on their environmental and societal risks and impacts. The main conclusion of the research is that while there is a minority of companies providing comprehensive and reliable sustainability-related information, at large quality and comparability of companies' sustainability reporting is not sufficient to understand their impacts, risks, or even their plans.

\subsection{Auditing and Assurance}

According to Article 34 of the Accounting Directive, Member States shall ensure that the financial statements are audited by one or more statutory auditors or audit firms approved by Member States to carry out statutory audits on the basis of 2006 Auditing Directive [6], as amended in 2014 [144]. The statutory auditor (s) or audit firm (s) shall also express an opinion on whether the management report is consistent with the financial statements for the same financial year, and (whether the management report has been prepared in accordance with the applicable legal requirements, state whether, in the light of the knowledge and understanding of the undertaking and its environment obtained in the course of the audit, he, she or it has identified material misstatements in the management report, and shall give an indication of the nature of any such misstatements. Same rules apply mutatis mutandis with respect to consolidated financial statements and consolidated management reports.

There is no requirement for auditing of corporate governance statements. However, according to Article 20 the statutory auditor or audit firm shall express an opinion if information referred to in certain detailed provisions in Article 20 has been provided. Article 34 does not apply at all to the non-financial statement referred to in Article 19a and the consolidated non-financial statement referred to in Article 29a or to the possible separate non-financial reports. According to Article 19a, Member States shall ensure only that the statutory auditor or audit firm checks whether the non-financial statement or the separate report has been provided. However, Member States may require that the information in the non-financial statement or the consolidated non-financial statement or in the separate report be verified by an independent assurance services provider.

According to Article 26 (1) of the Auditing Directive, Member States shall require statutory auditors and audit firms to carry out statutory audits in compliance with international auditing standards (defined in Article 26 (2) as International Standards on Auditing (ISA's), International Standard 
on Quality Control (ISQC 1) and other related Standards issued by the International Federation of Accountants (IFAC) through the International Auditing and Assurance Standards Board (IAASB), in so far as they are relevant to the statutory audit) adopted by the Commission. No international auditing standards have been adopted so far, so Member States may apply national auditing standards, procedures, or requirements if the Commission has not adopted an international auditing standard covering the same subject-matter. According to Article 26 (3), the Commission is empowered also to adopt the international auditing standards in the area of audit practice, independence and internal quality controls of statutory auditors and audit firms for the purposes of the application of those standards within the EU. According to Article 26 (5), where a Member State requires the statutory audit of small undertakings, it may provide that application of the auditing standards is to be proportionate to the scale and complexity of the activities of such undertakings. Member States may take measures to ensure the proportionate application of the auditing standards to the statutory audits of small undertakings ('scalability').

\subsection{Action Plan}

In its March 2018 Action Plan: Financing Sustainable Growth [7], the Commission recognised the importance of ensuring that accounting standards do not directly or indirectly discourage sustainable and long-term investments. In this regard, about the question is raised whether there could be more flexibility as concerns the endorsement of IFRSs wherever specific adjustments would be more conducive to long-term investment [7] (p. 10). Albeit endorsing the Non-Financial Reporting Directive, allowing disclosure of material information on key environmental, social and governance aspects and how risks stemming from them are managed, in a 'flexible manner', the Commission emphasised an appropriate balance between flexibility and the standardisation of disclosure, necessary to generate the data needed for investment decisions.

Specifically, the European Commission set in Action 9, Strengthening sustainability disclosure and accounting rulemaking [7] (pp. 10-11), six goals to reform reporting rules.

1. The Commission was to launch a fitness check of EU legislation on public corporate reporting, including Article 19a of the Accounting Directive to assess whether public reporting requirements for listed and non-listed companies are fit for purpose. It was to include the evaluation of sustainability reporting requirements and the prospects for digitalised reporting. The Commission was to launch a public consultation on this in 2018. The conclusions of the fitness check were to be published in 2019 and will inform any future legislative proposals to be adopted by the Commission. The Commission conducted the public consultation on fitness check on the EU framework for public reporting by companies in March-July 2018 [145]. The summary report of the consultation has been published in October 2018 [146]. The conclusions have not been published yet.

2. The Commission was to revise the guidelines on non-financial information. Building on the metrics to be developed by the Commission technical expert group on sustainable finance, the revised guidelines should provide further guidance to companies on how to disclose climate-related information, in line with the Financial Stability Board's Task Force on Climate-related Financial Disclosure (TCFD) and the climate-related metrics developed under the new classification system ('taxonomy'). Subsequently, the guidelines were to be amended to include other environmental and social factors. The supplementing Guidelines on reporting climate-related information were published in June 2019 [41]. The Guidelines incorporate the recommended disclosures of the Taskforce on Climate-related Financial Disclosures (TCFD), which are themselves aligned with other principal frameworks. The disclosures recommended by the TCFD are separately identified in these guidelines. Annex II of the Guidelines shows the disclosure requirements of the Non-Financial Reporting Directive mapped against the recommended disclosures of the TCFD. In addition to the TCFD, these guidelines also take particular account of the standards and frameworks developed by the GRI, the CDP, the Climate Disclosure Standards Board (CDSB), 
the Sustainability Accounting Standards Board (SASB) and the International Integrated Reporting Council (IIRC) and of the EU Eco-Management and Audit Scheme (EMAS).

3. A European Corporate Reporting Lab was to be established as part of the European Financial Reporting Advisory Group (EFRAG), to promote innovation and the development of best practices in corporate reporting, such as environmental accounting. In this forum, companies and investors can share best practices on sustainability reporting, such as the climate-related disclosure in line with the TCFD's recommendations [147].

4. In terms of disclosure by asset managers and institutional investors, as part of the Commission's legislative proposal in Action 7, they would be requested to disclose how they consider sustainability factors in their strategy and investment decision making process, in particular for their exposures to climate change-related risks. This was included in the Disclosure Regulation [148].

5. The Commission was to request EFRAG, where appropriate, to assess the impact of new or revised IFRSs on sustainable investments. The Commission was also to ask EFRAG to explore potential alternative accounting treatments to fair value measurement for long-term investment portfolios of equity and equity-type instruments. In 2018 the Commission was to report, considering EFRAG current work, on the impact of IFRS 9 on long-term investments and explore improvements to the standard for the treatment of equity instruments. In May 2019, the EFRAG launched a public consultation to gather constituents' views on whether alternative accounting treatments to those in IFRS 9 are needed to portray the performance and risks of equity and equity-type instruments held in long-term investment business models [149].

6. Within the fitness check of EU legislation (point 1 above) on public corporate reporting, the Commission was also to evaluate relevant aspects of the IAS Regulation. It was to explore how the adoption process of IFRSs can allow for specific adjustments to standards where they are not conducive to the European public good, e.g., where the standards could pose an obstacle to long-term investment objectives.

\section{Way Forward}

\subsection{Financial Reporting Reform: A Lost Case?}

According to the summary report of the public consultation on the fitness check on the EU framework for public reporting by companies [147], there is not much hope for a revision of the EU financial reporting regulation. The differences between the Member States as to how the Accounting Directive has been implemented is seen irrelevant, and there is no willingness for active reform of the IFRS. The IFRSs were effective as they helped reduce the cost of capital and increase investments in the EU, without any other considerations. Concerning the 'potential' impact of IFRSs on sustainable investments, whilst a few believed IFRS's had led to pro-cyclicality and short-termism, most respondents asserted that (to their knowledge) there was no evidence of such impacts. A majority of respondents supported the status quo as regards the EU IFRS endorsement process, and cautioned against 'EU carve-ins' that could lead to 'EU-IFRSs', a situation that could be detrimental to EU companies active globally and to foreign investments into the EU. Those who were in favour of 'EU carve-ins' did not see why the EU should not enjoy this power whilst other jurisdictions do. Some of them argued that 'carve-in' powers would increase the Union's ability to influence the IASB standard-setting process compared to the current 'yes-no' endorsement process.

The economic interests of investors are primary motives to use the IFRS as it is. The pro-cyclicality and short termism effects of the IFRS are recognized but mostly ignored, affirming the notion that financial reporting is ignorant to sustainability, the tools being found from direct regulation of corporate activities. It seems clear that the market actors close their eyes to the factors of how financial reporting rules hamper sustainability and long-term investments. As to the question of whether and how to integrate financial and non-financial reports in a meaningful way, most respondents 
answered that integrated reporting could indeed contribute to a more efficient allocation of capital and better decision-making.

In terms of safeguarding stakeholders' interests and ensuring financial stability, a majority believed that the reporting framework could have some effective role but saw prudential requirements as the most relevant way to address financial stability.

However, the IFRS is a major obstacle to sustainability.

\subsection{Way Forward? Integrated Report as a Non-Financial Report?}

During the preparation phase of the International $<\mathrm{IR}>$ Framework the ambitious target was to replace both sustainability reporting and financial reporting with integrated reporting. The $<\mathrm{IR}>$ was intended to be a response to the Global Financial Crisis 2007-2008 and the string of corporate failures which undermined confidence in conventional financial statements and highlighted the limitation of retrospective reporting on a single measure of organisational performance. The weaknesses in 'sustainability' reporting were also seen as relevant as traditional sustainability reports presented 'ESG' disclosures separately from financial information and did not always explain the interconnection between strategy, risks and the multiple forms of capital under an organisation's control [150].

This target was, however, soon downplayed both by the GRI and the standard setters. It was agreed in various Memoranda of Understanding with the most important standard setters, including GRI, the US Sustainability Accounting Standards Board (SASB), the Climate Disclosure Standard Board (CDSB), the UK Carbon Disclosure Project (CDP), the World Intellectual Capital Initiative (WICI), the International Federation of Accountants (IFAC) and the IASB as well as the Accounting for Sustainability (A4S), that integrated reporting, sustainability reporting and financial reporting are complementarities with assurance that integrated reporting would not 'colonize' existing reporting spaces [111] (pp. 47-49), [131] (p. 66). Additionally, the IIRC launched in 2014 the Corporate Reporting Dialogue (CRD) to address issues regarding materiality and quantitative information in cooperation with the GRI, the SASB, the CDSB, and the IASB. Currently, CRD includes additionally the US FASB, and the ISO [151]. Such a comprehensive and collective alliance could increase IIRC's difficulty in developing the International $<\mathrm{IR}>$ Framework, since it must consider the interests of a diverse range of CRD stakeholders [152] (p. 277).

Due to these memoranda, and the CRD, the International $<\mathrm{IR}>$ Framework does not create integrated reporting in the narrow sense, but a separate report both of existing financial reports prepared according to financial reporting standards as IFRS and traditional sustainability reports prepared according for instance GRI. What is important, $<\mathrm{IR}>$ does not cover sustainability [96] (p. 15), [51] (p. 20). 'Corporate social responsibility' and sustainability reports are targeted to the classical 'stakeholders', the $<\mathrm{IR}>$ addresses (institutional) investors both in equity and debt (investment supply chain), 'providers of financial capital to enable a more efficient and productive allocation of capital' [20] (p. 2). The $<\mathrm{IR}>$ does not address the decision-making and accountability needs of stakeholding publics such as consumers, employees, suppliers, local communities, NGOs, labour unions, social movements, governments, indigenous communities, developing countries and future generations [36] (p. 1133). Indeed, as Milne and Gray observe, even compared to the GRI, the IIRC's proposals are 'remarkably regressive' [51] (p. 25). As Brown and Dillard note, the $<$ IR> 'exhibit[s] a strong investor bias, with no attempt to open up substantive discussion on important-And contentious-Issues around corporate accountability or sustainability' [36] (p. 1133).

Taking this into consideration, it is no wonder that there is not much enthusiasm in the EU for integrated reporting. For instance according to the consultation on fitness check (see above), just over half of the respondents believed that integrated reporting could contribute to a more efficient allocation of capital (through improved quality of information to capital providers), and a similar proportion believed it could contribute also to better decision-making and risk management in companies. A minority of respondents believed that integrated reporting would lead to costs savings for report prepares or for users, with views considerably more negative in the case of possible cost savings 
for preparers. Just under half of the respondents believed that the costs of integrated reporting are proportionate to the benefits, while a quarter disagreed.

Additionally, just over half of the respondents agreed that the EU should encourage integrated reporting. Most business representatives called for integrated reporting not to be imposed by regulation. A clear majority of respondents believed that the existing EU framework on reporting is no obstacle for companies to move towards integrated reporting, and only a small minority believed the opposite. Many respondents argued that the Non-Financial Reporting Directive (Article 19a of the Accounting Directive) encourages integrated reporting because the management report is the default location of the non-financial statement. At the same time, the fact that most Member States allow companies to publish the non-financial statement in a separate report was believed by some stakeholders to be contrary to the promotion of integrated reporting.

Concerning assurance of integrated reporting there is no provisions on assurance in the International $<\mathrm{IR}>$ Framework. Assurance is, as following the Framework, totally voluntary. The most used standards for assurance are AA1000 Assurance Standard (AA1000AS), launched in 2008 by AccountAbility, and the International Audit Assurance Standards Board's (IAASB) International Standard on Assurance Engagements (ISAE 3000) [31] (p. 316).

Although Article 19a of the Accounting Directive was an important follow up to open the space for a discourse on how to report on the sustainability impacts of business, the lack of stringency and of verification requirements in the Directive means that it still open for unsustainable businesses to greenwash or now, SDG-wash-And difficult for businesses attempting to be sustainable, to show this to their potential contractual parties and to society at large. Article 19a (6) of the Directive leaves it to the Member States to require a verification by an independent assurance services provider. Otherwise, Member States shall only ensure that the statutory auditor or audit firm checks whether the non-financial statement or the separate report has been provided (Article 19a (5) of the Directive).

That the unsustainable businesses thereby still often have the competitive advantage is especially detrimental for European companies, notably from the Nordics and from some Continental-European countries, who have the potential of becoming the market-leaders of tomorrow if they have a regulatory framework that support their attempts at creating value in a sustainable way. On the other hand, the Nordic Member States do not take non-financial reporting seriously; to the contrary, implementation of the Non-Financial Reporting Directive was seen as a reason to exempt management report from full audit (as in Finland).

\subsection{Possible Solutions}

Based on the most recent developments in EU law, especially on the 2018 Action Plan on sustainable finance and its implementation both in governance and reporting, the European Green Deal and the European Green Deal Investment Plan, developments in the European Economic Area member states as well as on the research conducted by the SMART team, possible paths forward are envisaged to encourage true sustainability in reporting and through that, in governance. The timing for SMART team proposals is good as the European Commission launched in February 2020 a public consultation on the Non-Financial Reporting Directive [9].

In its introductory reform proposals published in November 2019 and revised in May 2020 [18] (pp. 11-12), the SMART team notes that the Non-Financial Reporting Directive, through which Article 19 a was added to the 2013 Accounting Directive, was an important follow up to open the space for a discourse on how to report on the sustainability impacts of business. However, the lack of stringency and of verification requirements in the Directive mean that it is difficult for businesses attempting to be sustainable, to show this to their potential contractual parties and society at large. It also remains possible for unsustainable businesses to greenwash or SDG-wash. That the unsustainable businesses thereby still often have the competitive advantage is especially detrimental for European companies who have the potential of becoming the market-leaders of tomorrow if they have a regulatory framework that support their attempts at creating value in a sustainable way. 
According to the SMART project, European businesses can become the market-leaders of tomorrow, if they have a regulatory framework that supports sustainable value creation. As a solution SMART project proposes that the EU clarifies and strengthens sustainability reporting requirements, to make them more stringent, and with requirements for external verification. This needs to be tied closely to the redefined duties of the board and the tools of sustainability assessment and sustainability due diligence proposed [18]. What is important, both board duties and reporting duties should be applied to all undertakings with limited liability, irrespective their corporate form, sector, or size. However, according a proposed scalability rule, the scale and complexity of the undertaking should be taken into consideration when applying the proposed rules. The SMART project suggested repealing the Non-Financial Reporting Directive [65] (Article 19a of the Accounting Directive [4] on non-financial statement) and the inclusion of sustainability requirements in Article 19 of the Accounting Directive on the management report to clarify that sustainability reporting is not something that is 'non-financial' and left to the company to report what they wish to say, relying on sustainability standards such as the Global Reporting Initiative (GRI) and Integrated Reporting, $<\mathrm{IR}>$, without clear regulatory requirements and clear requirements for compulsory assurance.

Further, the information should be under full audit according to Article 34 (1) first paragraph of the Accounting Directive. Sustainability reporting needs to be taken as seriously and be subject to equivalent requirements as those that apply to financial statements and consolidated financial statements, not according to the superficial 'consistency check' of Article 34 (1) second paragraph. Also, these proposals apply to all undertakings, with scalability in applying in reporting and auditing according to the applicable standards. This entails amending 2006 Auditing Directive of 2006 (as amended by Directive of 2014) [6] by adding international assurance standards to the European auditing framework to include management report under full audit.

\subsection{Connecting Duties of the Board to Sustainability Reporting}

\subsubsection{Management Report}

In its detailed reform proposals [153] (p. 61) the SMART team has proposed that the boards of all undertakings shall, every three years or more frequently in case of fundamental changes to the business model, ensure that a stringent sustainability assessment is carried out of the business of the undertaking. This shall include employing sustainability due diligence across the operations of its business, which shall cover environmental, social and governance issues, connected to the sustainability definition of securing the social foundation for humanity within planetary boundaries. Based on the sustainability assessment, the board shall identify ongoing negative sustainability impacts and principal risks of future negative sustainability impacts and select relevant quantitative and qualitative KPIs. In its identification and management of principal risks, the board shall be guided by a precautionary principle, entailing that where there are threats of serious or irreversible damage to nature or to humans, avoidance or mitigation of possible harm must be undertaken also in cases of scientific uncertainty. Where the negative impacts or risks thereof are caused by lack of legal compliance, the board must ensure that this is rectified as soon as possible. For other issues, a system for an ambitious continuous improvement process must be put into place.

Based on these proposals, forming the basis for meaningful sustainability reporting, the SMART team proposes an amendment of the rules on management report in Article 19 of the Accounting Directive to include rules for identification of ongoing negative sustainability impacts and principal risks of future negative sustainability impacts, and selected Key Performance Indicators, including, in the case the negative impacts or risks thereof are caused by lack of legal compliance, reporting on how they have been rectified. The European Commission delegated acts should give guidance for identification of ongoing negative sustainability impacts and principal risks of future negative sustainability impacts. The Commission guidance is proposed revised every three years, through an open participatory process, integrating expertise and affected communities [153] (p. 66). 
In addition, the SMART team proposed that the country-by-country reports for payments to governments and of income tax information, presently in Chapter 10 and in the Commission proposed and the Parliament adopted Chapter 10a of the Accounting Directive, should be added to Article 19 of the Directive. According to the present Article 42 (1) of the Directive Member States shall require large undertakings and all public-interest entities active in the extractive industry or the logging of primary forests to prepare and make public a report on payments made to governments on an annual basis. Instead of a separate report this information should be included in the management report, by amending Article 42 (1). In a similar vein, the Commission proposed, and the Parliament adopted Article 48b (1) on tax information should be included in the management report. Similar amendments should be made in Article 29 on the consolidated management report, with repeal of Article 29a on consolidated non-financial statement. Similar amendments in Article 44 and proposed Article 48b (3) on consolidated country-by-country reports should also be made, with a reference to Article 29 on consolidated management report [153] (p. 67).

The proposed amendment of Article 19 and repeal of Article 19a of the Accounting Directive do not require amendments in the Transparency Directive [153] (p. 68). According to Article 4 (5) of the Transparency Directive, the management report shall be drawn up in accordance with Article 46 of the Fourth Directive and, if the issuer is required to prepare consolidated accounts, in accordance with Article 36 of the Seventh Directive. These provisions are currently included in Articles 19 and 29 of the Accounting Directive. For clarity, the paragraph could be modernised without material amendments, with references to the provisions in force. As all information duties proposed in Articles 19 and 29, including country-by-country information reported according to Chapter 10 and the proposed 10a of the Accounting Directive, is to be given in management report, there is no need for other amendments to the wording of Article 4 of the Transparency Directive.

\subsubsection{Assurance}

The SMART team proposes also that the processes included in the sustainability assessment, the identification of the ongoing negative sustainability impacts and principal risks of future negative sustainability impacts as well as the selection of relevant Key Performance Indicators, shall be assured by independent experts. Such experts may, depending on the laws of each Member State, be natural or legal persons or companies or firms [21] (p. 61). Unlike in present provisions on auditing, all reporting needs to be taken as seriously and be subject to equivalent requirements as traditional financial reporting, not according to the superficial 'conformity check' of Article 34(1) second paragraph of the Accounting Directive. A 'full audit' of the management report is realistic [153] (p. 14). As stated in the European Commission Article 48 of the Accounting Directive review of country-by-country reporting requirements for extractive and logging industries, a full audit of the reports could increase the confidence of users in the accuracy of the figures and the compliance of the reports with the reporting requirements [138] (p. 14).

'Full audit' according to Article 34 (1) (1) Accounting Directive would require revision of the provision so that Member States shall ensure that the financial statements of undertakings are audited and management reports are assured by one or more statutory auditors or audit firms approved by Member States to carry out statutory audits on the basis of the Auditing Directive [6]. The SMART team proposes that the information provided in the management report under Articles 19 and 29 of the Accounting Directive should be under full audit according to Article 34 (1) first paragraph of the Accounting Directive. Also, these proposals apply to all undertakings with limited liability, as all SMART team proposals. To ensure full audit of the management report, the Auditing Directive should be amended by adding international assurance standards to the European auditing framework to include management report under full audit. The international auditing standards referred to in Article 26 of the Auditing Directive should include International Standard on Assurance Engagements ISAE 3000 (Revised), Assurance Engagements Other than Audits or Reviews of Historical Financial Information, that can be applied to assurance of different kind of emerging forms of external reporting (EER), 
to create greater trust in the resulting assurance reports by users of EER, to assure that relevant, reliable, confidence-creating, comparable and accurate information has been provided [153]. The ISAE 3000 framework is still very general and would need to be tailored to the specific reporting regime to define the scope [153] (p. 68).

Transparency Directive. These amendments require an amendment also in Article 4 (4) (1) of the Transparency Directive stipulating that the financial statements shall be audited in accordance with Articles 51 and 51a of the Fourth Directive and, if the issuer is required to prepare consolidated accounts, in accordance with Article 37 of the Seventh Directive. As these directives has been repealed and replaced by Accounting Directive and in line with proposals in Articles 19 and 34 of the Accounting Directive, the SMART team proposes that the financial statements and the management report, and, if the issuer is required to prepare consolidated accounts and consolidated management report, the consolidated financial statements and the consolidated management report, shall be audited in accordance with Article 34 of Accounting Directive.

\section{Conclusions}

The European Commission presented in December 2019 the European Green Deal, a package of measures that should 'enable European citizens and businesses to benefit from sustainable green transition' that is just and socially fair [8]. This would mean renewing the sustainable finance strategy, embedding sustainability further into the corporate governance framework and increasing disclosure on climate and environmental data so that investors are fully informed about the sustainability of their investments.

To this end, the Commission will review the Non-Financial Reporting Directive. To ensure appropriate management of environmental risks and mitigation opportunities, and reduce related transaction costs, the Commission will also support businesses and other stakeholders in developing 'standardised natural capital accounting practices within the EU and internationally' [8] (p. 17). The timetable for the Commission actions is ambitious, renewed sustainable finance strategy in autumn 2020 and review of the Non-Financial Reporting Directive before the end of 2020 [154].

In this research the financial, environmental, social, and integrated reporting frameworks are analysed to find their weaknesses and strengths in supporting in a reliable way sustainable governance.

The results of this research and the concrete regulatory proposals based on them support the Commission's conclusions. In this research the flaws of both financial reporting and environmental, social, and integrated reporting are discussed in depth, and concrete reform proposals for amendments of the EU regulatory framework for corporate reporting and assurance of given information is given.

Funding: This research was funded by the European Union under the Horizon 2020 programme, grant agreement 693642. The contents of this article are the sole responsibility of the authors and do not necessarily reflect the views of the European Union.

Acknowledgments: The author wishes to thank anonymous reviewers for their comments on the original draft, academic colleagues and practitioners contributing to in the research conducted under Work Package 2 of the project Sustainable Market Actors and Responsible Trade (SMART), as well as the lead author, Beate Sjåfjell and the other co-authors, Tonia Novitz, Clair Gammage and Hanna Ahlström, of the SMART Report 'Securing the Future of European Business: SMART Reform Proposals', University of Oslo Faculty of Law Research Paper No. 2020-11, https://ssrn.com/abstract=3595048, on which sections of this article draws.

Conflicts of Interest: The author declares no conflict of interest.

\section{References and Notes}

1. Freeman, R.E. Strategic Management: A Stakeholder Approach; Pitman: Boston, MA, USA, 1984.

2. Gray, R. Social and Environmental Accounting and Reporting: From Ridicule to Revolution? From Hope to Hubris?-A Personal Review of the Field. Issues Soc. Environ. Acc. 2008, 2, 3-18. [CrossRef]

3. Moneva, J.M.; Archel, P.; Correa, C. GRI and the camouflaging of corporate unsustainability. Account. Forum 2006, 30, 121-137. [CrossRef] 
4. Directive 2013/34/EU of the European Parliament and of the Council of 26 June 2013 on the Annual Financial Statements, Consolidated Financial Statements and Related Reports of Certain Types of Undertakings, Amending Directive 2006/43/EC of the European Parliament and of the Council and Repealing Council Directives 78/660/EEC and 83/349/EEC; OJ L 182; European Union: Brussels, Belgium, 2013; pp. 19-76.

5. Regulation (EC) No 1606/2002 of the European Parliament and of the Council of 19 July 2002 on the Application of International Accounting Standards; OJ L 243; European Union: Brussels, Belgium, 2002; pp. 1-4.

6. Directive 2006/43/EC of the European Parliament and of the Council of 17 May 2006 on Statutory Audits of Annual Accounts and Consolidated Accounts, amending Council Directives 78/660/EEC and 83/349/EEC and repealing Council Directive 84/253/EEC; OJ L 157; European Union: Strasbourg, France, 2006; pp. 87-107.

7. European Commission. Communication from the Commission to the European Parliament, the European Council, the Council, the European Central Bank, the European Economic and Social Committee and the Committee of the Regions: Action Plan.: Financing Sustainable Growth; (8.3.2018, COM/2018/097 Final); European Commission: Brussels, Belgium, 2018.

8. European Commission. European Commission. Communication from the Commission to the European Parliament, the European Council, the Council, the European Economic and Social Committee and the Committee of the Regions: The European Green Deal, 11.12.2019. COM(2019) 640 Final. Available online: https://ec.europa.eu/info/sites/info/files/european-green-deal-communication_en.pdf (accessed on 27 December 2019).

9. European Council, the Council, the European Economic and Social Committee and the Committee of the Regions. Sustainable Europe Investment Plan-European Green Deal Investment Plan. COM(2020) 21 Final. 14 January 2020. Available online: https://ec.europa.eu/commission/presscorner/detail/en/fs_20_48 (accessed on 14 January 2020).

10. EU High-Level Group on Sustainable Finance. Financing a Sustainable European Economy. Final Report. 2018. Available online: https:/ec.europa.eu/info/sites/info/files/180131-sustainable-finance-final-report_en.pdf (accessed on 1 November 2019).

11. Hueskes, M.; Verhoest, K.; Block, T. Governing public-private partnerships for sustainability: An analysis of procurement and governance practices of PPP infrastructure projects. Int. J. Proj. Manag. 2017, 35, 1184-1195. [CrossRef]

12. Roome, N. Looking Back, Thinking Forward: Distinguishing Between Weak and Strong Sustainability. In The Oxford Handbook of Business and the Natural Environment; Bansal, P., Hoffman, A.J., Eds.; Oxford University Press: Oxford, UK, 2011. [CrossRef]

13. Sustainable Market Actors for Responsible Trade (SMART). Available online: www.smart.uio.no (accessed on 1 November 2019).

14. Sustainable Market Actors for Responsible Trade (SMART). Events. Available online: https://www.smart.uio. no/events/events/ (accessed on 17 June 2020).

15. On Planetary Boundaries See Stockholm Resilience Centre, Planetary Boundaries Research. Available online: https://www.stockholmresilience.org/research/planetary-boundaries.html (accessed on 1 November 2019).

16. Leach, M.; Raworth, K.; Rockström, J. Between Social and Planetary Boundaries: Navigating Pathways in the Safe and Just Space for Humanity. In World Social Science Report 2013; OECD Publishing: Paris, France, 2013; pp. 84-90.

17. Sjåfjell, B.; Mähönen, J.; Taylor, M.; Maitre-Ekern, E.; van der Velden, M.; Novitz, T.; Gammage, C.; Cullen, J.; Andhov, M.; Caranta, R. SMART DELIVERABLE 2.7: Supporting the Transition to Sustainability: SMART Reform Proposals. First Version. Submitted 14 November 2019. Available online: https://www.smart. uio.no/publications/reports/smart-d2.7-supporting-the-transition-to-sustainability-2019.pdf (accessed on 1 November 2019).

18. Sjåfjell, B.; Mähönen, J.; Taylor, M.B.; Maitre-Ekern, E.; van der Velden, M.; Novitz, T.A.; Gammage, C.; Cullen, J.; Andhov, M.; Caranta, R. Supporting the Transition to Sustainability: SMART Reform Proposals. University of Oslo Faculty of Law Research Paper No. 2019-63; Nordic \& European Company Law Working Paper No. 20-05. 13 December 2019. Available online: https://ssrn.com/abstract $=3503310$ (accessed on 1 June 2020).

19. Global Reporting Initiative. Available online: www.globalreporting.org (accessed on 1 November 2019). 
20. The International Integrated Reporting Council. The International <IR $>$ Framework. Available online: http://integratedreporting.org/wp-content/uploads/2015/03/13-12-08-THE-INTERNATIONAL-IRFRAMEWORK-2-1.pdf (accessed on 1 November 2019).

21. Sjåfjell, B.; Mähönen, J.; Novitz, T.A.; Gammage, C.; Ahlström, H. Securing the Future of European Business: SMART Reform Proposals. University of Oslo Faculty of Law Research Paper No. 2020-11. 7 May 2020. Available online: https://ssrn.com/abstract=3595048 (accessed on 1 June 2020).

22. Eccles, R.G.; Spiesshofer, B. Integrated Reporting for a Re-Imagined Capitalism. Harvard Business School General Management Unit Working Paper No. 16-032. 25 September 2015. Available online: https: //ssrn.com/abstract=2665737 (accessed on 1 November 2019). [CrossRef]

23. Baker, C.R.; Quéré, B.B. The role of the state in corporate governance. Account. Hist. 2014, 19, $291-307$. [CrossRef]

24. Littleton, A.C. Accounting Evolution to 1900; Russell and Russell: New York, NY, USA, 1933.

25. Gleeson-White, J. Six Capitals: The Revolution Capitalism Has to Have-Or Can. Accountants Save the Planet? Allen and Unwin: Sydney, Australia, 2014.

26. Examples of these classifications can be found from the financial reporting standards as International Accounting Standard Board's Conceptual Framework for Financial Reporting and International Financial Reporting Standard 9 Financial Instruments or the Financial Accounting Standard Board's Conceptual Framework and Accounting Standards Codification Topic 480 Distinguishing Liabilities from Equity, as well as Accounting Standards Updates related to the Topic.

27. Dean, G.; Clarke, F.; Capalbo, F. Pacioli's double entry-Part of an intellectual and social movement. Account. Hist. Rev. 2016, 26, 5-24. [CrossRef]

28. Especially as a 'goodwill', see, e.g., International Accounting Standards Board, International Financial Reporting Standard 3 Business Combinations.

29. Kassai, J.R.; Carvalho, N. Integrated Reporting: When, Why and How Did It Happen? In Integrated Reporting: A New Accounting Disclosure; Mio, C., Ed.; Palgrave Macmillan: London, UK, 2016; pp. 109-116.

30. Tsagas, G. Section 172 of the Companies Act 2006: Desperate Times call for Soft Law Measures. In Shaping the Corporate Landscape: Towards Corporate Reform and Enterprise Diversity; Boeger, N., Villiers, C., Eds.; Hart Publishing: Oxford, UK, 2018; pp. 131-150.

31. Velte, P.; Stawinoga, M. Integrated reporting: The current state of empirical research, limitations and future research implications. J. Manag. Control. 2017, 28, 275-320. [CrossRef]

32. Directive 2014/95/EU of the European Parliament and of the Council of 22 October 2014 Amending Directive 2013/34/EU as Regards Disclosure of Non-Financial and Diversity Information by Certain large undertakings and groups; OJ L 330; European Union: Brussels, Belgium, 2014; pp. 1-9.

33. Fagerström, A.; Hartwig, F.; Cunningham, G. Accounting and Auditing of Sustainability: Sustainable Indicator Accounting (SIA). Sustain. J. Rec. 2017, 10, 45-52. [CrossRef]

34. Hess, D. The Future of Sustainability Reporting as a Regulatory Mechanism. In Law and the Transition to Business Sustainability; Cahoy, D.R., Colburn, J.E., Eds.; Springer: Berlin/Heidelberg, Germany, 2014; pp. 125-139.

35. Bebbington, J.; Thomson, I. Sustainable development, management and accounting: Boundary crossing. Manag. Account. Res. 2013, 24, 277-283. [CrossRef]

36. Brown, J.; Dillard, J. Integrated reporting: On the need for broadening out and opening up. Account. Audit. Account. J. 2014, 27, 1120-1156. [CrossRef]

37. International Integrated Reporting Council. Available online: http://integratedreporting.org (accessed on 1 November 2019).

38. Adams, C.A. The International Integrated Reporting Council: A call to action. Crit. Perspect. Account. 2015, 27, 23-28. [CrossRef]

39. Druckman, P. Foreword. In Integrated Reporting: A New Accounting Disclosure; Mio, C., Ed.; Palgrave Macmillan: London, UK, 2016; pp. 5-11.

40. European Commission. Communication from the Commission-Guidelines on Non-Financial Reporting (Methodology for Reporting Non-Financial Information); C/2017/4234, OJ C 215; European Commission: Brussels, Belgium, 2017; pp. 1-20. 
41. European Commission. Communication from the Commission-Guidelines on Non-Financial Reporting: Supplement on Reporting Climate-Related Information; C/2019/4490, OJ C 209; European Commission: Brussels, Belgium, 2019; pp. 1-30.

42. Thornton, D.B. Green accounting and green eyeshades twenty years later. Crit. Perspect. Account. 2013, 24, 438-442. [CrossRef]

43. Deegan, C. The accountant will have a central role in saving the planet ... really? A reflection on 'green accounting and green eyeshades twenty years later'. Crit. Perspect. Account. 2013, 24, 448-458. [CrossRef]

44. Bebbington, J.; Gray, R. An account of sustainability: Failure, success and a reconceptualization. Crit. Perspect. Account. 2001, 12, 557-587. [CrossRef]

45. IFRS Foundation. Conceptual Framework for Financial Reporting (Issued by the International Accounting Standards Board in September 2010, Revised in March 2018). Available online: https://www.ifrs.org/issuedstandards/list-of-standards/conceptual-framework/ (accessed on 1 November 2019).

46. European Parliament Resolution of 6 October 2016 on International Financial Reporting Standards: IFRS 9 (2016/2898(RSP)). Available online: http://www.europarl.europa.eu/doceo/document/TA-8-2016-0381_EN. html?redirect (accessed on 1 November 2019).

47. EU High-Level Expert Group on Sustainable Finance. Financing a Sustainable European Economy: Interim Report. July 2017. Available online: https://ec.europa.eu/info/publications/170713-sustainable-financereport_en (accessed on 1 November 2019).

48. Bebbington, J.; Larrinaga, C. Accounting and sustainable development: An exploration. Account. Organ. Soc. 2014, 39, 395-413. [CrossRef]

49. Elkington, J. Cannibals with Forks: The Triple Bottom Line of 21. Century Business; Capstone: Oxford, UK, 1997.

50. Hugé, J.; Waas, T.; Dahdouh-Guebas, F.; Koedam, N.; Thomas Block, T. A discourse-analytical perspective on sustainability assessment: Interpreting sustainable development in practice. Sustain. Sci. 2013, 8, 187-198. [CrossRef]

51. Milne, M.J.; Gray, R. W(h)ither Ecology? The Triple Bottom Line, the Global Reporting Initiative, and Corporate Sustainability Reporting. J. Bus. Ethics 2013, 118, 13-29. [CrossRef]

52. Landrum, N.L.; Ohsowski, B. Identifying Worldviews on Corporate Sustainability: A Content Analysis of Corporate Sustainability Reports. Bus. Strategy Environ. 2018, 27, 128-151. [CrossRef]

53. Tweedie, D.; Martinov-Bennie, N. Entitlements and Time: Integrated Reporting's Double-edged Agenda. Soc. Environ. Account. J. 2015, 35, 49-61. [CrossRef]

54. Marsden, C. Economics, the Financial Crisis and Corporate Responsibility. Corp. Gov. Int. J. Bus. Soc. 2010, 10, 360-364. [CrossRef]

55. Esser, I.-M. Corporate Social Responsibility: A Company Law Perspective. S. Afr. Merc. Law J. 2011, 23, 317-335.

56. Szabó, D.G.; Sørensen, K.E. Integrating Corporate Social Responsibility in Corporate Governance Codes in the EU. Eur. Bus. Law Rev. 2013, 24, 781-828.

57. Harper Ho, V. "Enlightened Shareholder Value”: Corporate Governance beyond the Shareholder-Stakeholder Divide. J. Corp. Law 2010, 36, 59-112. [CrossRef]

58. Keay, A. Moving towards Stakeholderism? Constituency Statutes, Enlightened Shareholder Value, and More: Much Ado about Little? Eur. Bus. Law Rev. 2011, 22, 1-49.

59. Keay, A. The Enlightened Shareholder Value Principle and Corporate Governance; Routledge: Abingdon, UK, 2013.

60. Lombard, S.; Joubert, T. The Legislative Response to the Shareholders V Stakeholders Debate: A Comparative Overview. J. Corp. Law Stud. 2014, 14, 211-240. [CrossRef]

61. Keay, A. The Corporate Objective; Edward Elgar: Oxford, UK, 2011.

62. Adams, C.A.; Whelan, G. Conceptualising future change in corporate sustainability reporting. Account. Audit. Account. J. 2009, 22, 118-143. [CrossRef]

63. Neumayer, E. Weak Versus Strong Sustainability: Exploring the Limits of Two Opposing Paradigms; Edward Elgar Publishing: Cheltenham, UK, 2003.

64. Holden, E.; Linnerud, K.; Banister, D. Sustainable development: Our Common Future revisited. Glob. Environ. Chang. 2014, 26, 130-139. [CrossRef]

65. Ekins, P.; Simon, S.; Deutsch, L.; Folke, C.; De Groot, R. A framework for the practical application of the concepts of critical natural capital and strong sustainability. Ecol. Econ. 2003, 44, 165-185. [CrossRef] 
66. Victor, P.A. Indicators of sustainable development: Some lessons from capital theory. Ecol. Econ. 1991, 4, 191-213. [CrossRef]

67. World Forum on Natural Capital. What Is Natural Capital? Available online: https://naturalcapitalforum. com/about/ (accessed on 1 November 2019).

68. Natural Capital Coalition. What Is Natural Capital? Available online: https://naturalcapitalcoalition.org/ natural-capital-2/ (accessed on 1 November 2019).

69. Daly, D.E.; Farley, J. Ecological Economics: Principles and Applications, 2nd ed.; Island Press: Washington, DC, USA, 2011.

70. Levy, D.L.; Szejnwald Brown, H.; de Jong, M. The Contested Politics of Corporate Governance: The Case of the Global Reporting Initiative. Bus. Soc. 2010, 49, 88-115. [CrossRef]

71. Stubbs, W.; Higgins, C. Stakeholders' Perspectives on the Role of Regulatory Reform in Integrated Reporting. J. Bus. Ethics 2018, 147, 489-508. [CrossRef]

72. Reuter, M.; Messner, M. Lobbying on the integrated reporting framework: An analysis of comment letters to the 2011 discussion paper of the IIRC. Account. Audit. Account. J. 2015, 28, 365-402. [CrossRef]

73. Villiers, C.; Mähönen, J. Accounting, Auditing and Reporting: Supporting or Obstructing the Sustainable Companies Objective? In Company Law and Sustainability; Sjåfjell, B., Richardson, B.J., Eds.; Cambridge University Press: Cambridge, UK, 2015; pp. 175-225.

74. Villiers, C.; Mähönen, J. Article 11: Integrated Reporting or Non-Financial Reporting? In The Greening of European Business under EU Law; Sjåfjell, B., Wiesbrock, A., Eds.; Routledge: Oxon, UK, 2015; pp. $274-311$.

75. Johnston, A. Climate-Related Financial Disclosures: What Next for Environmental Sustainability? University of Oslo Faculty of Law Research Paper No. 2018-02. Available online: https://papers.ssrn.com/sol3/papers. cfm?abstract_id=3122259 (accessed on 1 November 2019).

76. Cheng, M.; Green, W.; Conradie, P.; Konishi, N.; Romi, A. The international integrated reporting framework: Key issues and future research opportunities. J. Int. Financ. Manag. Account. 2014, 25, 90-119. [CrossRef]

77. Idowu, S.O.; Del Baldo, M. (Eds.) Integrated Reporting: Antecedents and Perspectives for Organizations and Stakeholders; Springer: Cham, Switzerland, 2019.

78. de Villiers, C.; Rinaldi, L.; Unerman, J. Integrated Reporting: Insights, gaps and an agenda for future research. Account. Audit. Account. J. 2014, 27, 1042-1067. [CrossRef]

79. Eccles, R.C.; Krzus, M.P.; Ribot, S. The Integrated Reporting Movement: Meaning, Momentum, Motives, and Materiality; John Wiley \& Sons: Hoboken, NJ, USA, 2015.

80. Monciardini, D.; Dumay, J.; Biondi, L. Integrated Reporting and EU Law: Competing, Converging or Complementary Regulatory Frameworks? University of Oslo Faculty of Law Research Paper, No. 2017-23. 6 June 2017. Available online: https://ssrn.com/abstract=2981674 (accessed on 1 November 2019).

81. Adhariani, D.; de Villiers, C. Integrated reporting: Perspectives of corporate report preparers and other stakeholders. Sustain. Account. Manag. Policy J. 2019, 10, 183-207. [CrossRef]

82. Integrated Reporting $<\mathrm{IR}>$. New Malaysian Corporate Governance Code calls on companies to move towards Integrated Reporting. Available online: https://integratedreporting.org/news/new-malaysiancorporate-governance-code-calls-on-companies-to-move-towards-integrated-reporting/ (accessed on 1 November 2019).

83. Patajo-Kapunan, L. New Code of Corporate Governance for Publicly Listed Companies. 12 February 2017. Available online: http://www.businessmirror.com.ph/new-code-of-corporate-governance-for-publicly-listedcompanies/ (accessed on 1 November 2019).

84. The Institute of Directors in Southern Africa. King IV Report on Corporate Governance for South Africa 2016 (King IV). Available online: https://cdn.ymaws.com/www.iodsa.co.za/resource/collection/684B68A7B768-465C-8214-E3A007F15A5A/IoDSA_King_IV_Report_-_WebVersion.pdf (accessed on 17 June 2020).

85. Tweedie, D.; Nielsen, C.; Martinov-Bennie, N. The Business Model in Integrated Reporting: Evaluating Concept and Application. Aust. Account. Rev. 2018, 28, 405-420. [CrossRef]

86. Churet, C.; Eccles, R.G. Integrated Reporting, Quality of Management, and Financial Performance. J. Appl. Corp. Financ. 2014, 26, 8-16.

87. Page, M.; Spira, L.F. Corporate governance as custodianship of the business model. J. Manag. Gov. 2016, 20, 213-228. [CrossRef]

88. Teece, D.J. Business Models, Business Strategy and Innovation. Long Range Plan. 2010, 43, 172-194. [CrossRef] 
89. Bocken, N.M.P.; Short, S.W.; Rana, P.; Evans, S. A literature and practice review to develop sustainable business model archetypes'. J. Clean. Prod. 2014, 65, 42-56. [CrossRef]

90. Patala, S.; Jalkala, A.; Keränen, J.; Väisänen, S.; Tuominen, V.; Soukka, R. Sustainable value propositions: Framework and implications for technology suppliers. Ind. Mark. Manag. 2016, 59, 144-156. [CrossRef]

91. Lüdeke-Freund, F.; Carroux, S.; Joyce, A.; Massa, L.; Breuer, H. The sustainable business model pattern taxonomy-45 patterns to support sustainability-oriented business model innovation. Sustain. Prod. Consum. 2018, 15, 145-162. [CrossRef]

92. Du Plessis, J.J.; Rühmkorf, A. New trends regarding sustainability and integrated reporting for companies: What protection do directors have? Co. Lawyer 2015, 36, 49-62.

93. Oliver, J.; Vesty, G.; Brooks, A. Conceptualising integrated thinking in practice. Manag. Audit. J. 2016, 31, 228-248. [CrossRef]

94. Haller, A. Value Creation: A Core Concept of Integrated Reporting. In Integrated Reporting: A New Accounting Disclosure; Mio, C., Ed.; Palgrave Macmillan: London, UK, 2016; pp. 37-57.

95. Barker, R.; Kasim, T. Integrated Reporting: Precursor of a Paradigm Shift in Corporate Reporting? In Integrated Reporting: A New Accounting Disclosure; Mio, C., Ed.; Palgrave Macmillan: London, UK, 2016; pp. 81-108.

96. Adams, S.; Simnett, R. Integrated Reporting: An Opportunity for Australia's Not-for-Profit Sector. Aust. Account. Rev. 2011, 21, 292-301. [CrossRef]

97. Flower, J. The International Integrated Reporting Council: A story of failure. Crit. Perspect. Account. 2015, 27, 1-17. [CrossRef]

98. de Villiers, C.; Sharma, U. A Critical Reflection on the Future of Financial, Intellectual Capital, Sustainability and Integrated Reporting. Crit. Perspect. Account. 2017. [CrossRef]

99. de Villiers, C.; Venter, E.R.; Hsiao, P.-C.K. Integrated reporting: Background, measurement issues, approaches and an agenda for future research. Account. Financ. 2017, 57, 937-959. [CrossRef]

100. Dumay, J.; Dai, T. Integrated thinking as a cultural control? Meditari Account. Res. 2017, 25, 574-604. [CrossRef]

101. Report of the Committee on the Financial Aspects of Corporate Governance (Cadbury Report). 1 December 1992. Available online: https:/www.icaew.com/-/media/corporate/files/library/subjects/ corporate-governance/financial-aspects-of-corporate-governance.ashx?la=en (accessed on 17 June 2020).

102. Du Plessis, J.J.; Low, C.K. Corporate Governance Codes under the Spotlight. In Corporate Governance Codes for the 21st Century: International Perspectives and Critical Analyses; Du Plessis, J.J., Low, C.K., Eds.; Springer: Cham, Switzerland, 2017; pp. 3-20.

103. Keay, A. An Analytical Study of Board Accountability in Transnational Codes of Corporate Governance. In Corporate Governance Codes for the 21st Century: International Perspectives and Critical Analyses; Du Plessis, J.J., Low, C.K., Eds.; Springer: Cham, Switzerland, 2017; pp. 117-143.

104. Aguilera, R.V.; Cuervo-Cazurra, A. Codes of Good Governance Worldwide: What is the Trigger? Organ. Stud. 2004, 25, 417-446. [CrossRef]

105. Guillén, M.F. Corporate Governance and Globalization: Is There Convergence Across Countries? In Theories of Corporate Governance: The Philosophical Foundations of Corporate Governance; Clarke, T., Ed.; Routledge: London, UK; New York, NY, USA, 2004; pp. 223-242.

106. Klettner, A.; Clarke, T.; Boersma, M. The Governance of Corporate Sustainability: Empirical Insights into the Development, Leadership and Implementation of Responsible Business Strategy. J. Bus. Ethics 2014, 122, 145-165. [CrossRef]

107. Esser, I.-M. Corporate Governance: Soft Law Regulation and Disclosure-The Cases of the United Kingdom and South Africa. In Corporate Governance Codes for the 21st Century: International Perspectives and Critical Analyses; Du Plessis, J.J., Low, C.K., Eds.; Springer: Cham, Switzerland, 2017; pp. 233-260.

108. United Nations Environment Programme. Integrated Governance: A New Model of Governance for Sustainability; Asset Management Working Group of the United Nations Environment Programme Finance Initiative: Genève, Switzerland, June 2014; Available online: https://www.unepfi.org/fileadmin/documents/UNEPFI_ IntegratedGovernance.pdf (accessed on 17 June 2020).

109. Thomson, I. 'But does sustainability need capitalism or an integrated report' a commentary on 'The International Integrated Reporting Council: A story of failure' by Flower, J. Crit. Perspect. Account. 2015, 27, 18-22. [CrossRef] 
110. Rodrigue, M. The International Integrated Reporting Council: A Story of Failure; 'But Does Sustainability need Capitalism or an Integrated Report' a Commentary on 'The International Integrated Reporting Council: A Story of Failure' by Flower, J.; The International Integrated Reporting Council: A Call to Action. Soc. Environ. Account. J. 2015, 35, 128-129.

111. Humphrey, C.; O'Dwyer, B.; Unerman, J. Re-theorizing the configuration of organizational fields: The IIRC and the pursuit of 'Enlightened' corporate reporting. Account. Bus. Res. 2017, 47, 30-63. [CrossRef]

112. Ramalho, A. The Link between Codes of Corporate Governance and Sustainability. Available online: http://www.ifc.org/wps/wcm/connect/ebe8cba8-0d7b-402c-96d3-fd646e01a218/Sustainability_ considerations.pdf?MOD=AJPERES (accessed on 1 November 2019).

113. World Commission on Environment and Development. Our Common Future; Oxford University Press: Oxford, UK, 1987.

114. Institute of Directors in South Africa. King Code of Governance South Africa 2009 (King III). Available online: https://cdn.ymaws.com/www.iodsa.co.za/resource/resmgr/king_iii/King_Report_on_Governance_ fo.pdf (accessed on 17 June 2018).

115. Roberts, L.G. Integrated Reporting: The South African Experience. The CPA Journal: The Voice of the Profession. July 2017. Available online: https://www.cpajournal.com/2017/07/28/integrated-reporting-southafrican-experience/ (accessed on 17 June 2020).

116. International Integrated Reporting Council. IRC of South Africa: Integrated Reporting Is a Key Feature of King IV. 2 November 2016. Available online: http://integratedreporting.org/news/irc-of-south-africaintegrated-reporting-is-a-key-feature-of-king-iv/ (accessed on 1 November 2019).

117. Integrated Reporting Committee of South Africa. Guidance in South Africa. Available online: http: //integratedreportingsa.org/integrated-reporting/guidance/ (accessed on 1 November 2019).

118. Dumay, J.; Bernardi, C.; Guthrie, J.; La Torre, M. Barriers to Implementing the International Integrated Reporting Framework: A Contemporary Academic Perspective. Meditari Account. Res. 2017, 25, 461-480. [CrossRef]

119. Securities Commission Malaysia. Malaysian Code on Corporate Governance. 2017. Available online: https: //www.sc.com.my/api/documentms/download.ashx?id=70a5568b-1937-4d2b-8cbf-3aefed112c0a (accessed on 1 November 2019).

120. Under the Malaysian Code on Corporate Governance (p. 3, para. 2.6) large companies are companies on the FTSE Bursa Malaysia Top 100 Index; or companies with market capitalisation of RM2 billion and above, at the start of the companies' financial year. Once a company is under the category of large companies, it will remain as one for the entire financial year regardless of the change in its status during the financial year.

121. Sejati, Y.A.; Jones, C.R. The Impact of Malaysian Code on Corporate Governance and Political Connections on Accounting Conservatism. J. Account. Financ. 2019, 19, 115-132.

122. Hamad, S.; Draz, M.U.; Lai, F.-W. The Impact of Corporate Governance and Sustainability Reporting on Integrated Reporting: A Conceptual Framework. SAGE Open 2020, 10. [CrossRef]

123. KPMG: Malaysia's Top 100 Leads Sustainability Reporting Practices. Borneo Post Online. 25 October 2018. Available online: https://www.theborneopost.com/2017/10/25/kpmg-malaysias-top-100-leads-sustainabilityreporting-practices/ (accessed on 1 November 2019).

124. Jalila, J.; Komathy. Sustainability reporting and firm performance: Evidence in Malaysia. Int. J. Account. Financ. Bus. 2019, 4, 32-45.

125. An MIA-ACCA report sheds light on IR in Malaysia: Malaysian companies are eager to gain knowledge about integrated reporting and how it can benefit the organisation and its stakeholders, says a new MIA-ACCA report. ACCA Think Ahead. 1 November 2016. Available online: https://www.accaglobal.com/an/en/member/ member/accounting-business/2016/11-12/in-focus/ir-future.html (accessed on 17 June 2020).

126. Jaffar, N.; Nor, A.Z.M.; Selamat, Z. Analysis of Voluntary Disclosure before and After the Establishment of the Integrated Reporting Framework. Account. Financ. Rev. 2018, 3, 105-113.

127. Marcon, C.; Mancin, M. Empirical Evidence on Current Integrated Reporting Practices. In Integrated Reporting: A New Accounting Disclosure; Mio, C., Ed.; Palgrave Macmillan: London, UK, 2016; pp. 59-80.

128. Haji, A.A.; Hossain, D.M. Exploring the implications of integrated reporting on organisational reporting practice: Evidence from highly regarded integrated reporters. Qual. Res. Account. Manag. 2016, 13, 415-444. [CrossRef] 
129. Higgins, C.; Stubbs, W.; Love, T. Walking the talk(s): Organisational narratives of integrated reporting. Account. Audit. Account. J. 2014, 27, 1090-1119. [CrossRef]

130. Mio, C. Integrated Reporting: The IIRC Framework. In Integrated Reporting: A New Accounting Disclosure; Mio, C., Ed.; Palgrave Macmillan: London, UK, 2016; pp. 1-18.

131. Katsikas, E.; Rossi, F.M.; Orelli, R.L. Towards Integrated Reporting: Accounting Change in the Public Sector; Springer: Cham, Switzerland, 2017.

132. Fourth Council Directive 78/660/EEC of 25 July 1978 Based on Article 54(3)(g) of the Treaty on the Annual Accounts of Certain Types of Companies; OJ 1978, L 222; European Union: Brussels, Belgium, 1978.

133. Seventh Council Directive 83/349/EEC of 13 June 1983 Based on Article 54(3)(g) of the Treaty on Consolidated Accounts; OJ 1983, L 193; European Union: Brussels, Belgium, 1983.

134. European Commission. Communication from the European Commission, Accounting Harmonization: A New Strategy vis-à-vis International Harmonization; COM(95)508 NL; European Commission: Brussels, Belgium, 1995.

135. European Commission. Communication from the European Commission to the Council and the European Parliament, EU Financial Reporting Strategy: The Way Forward; COM(2000)359 Final; European Commission: Brussels, Belgium, 2000.

136. European Commission. Proposal for a Regulation of the European Parliament and of the Council on the Application of International Accounting Standards of 13 February 2001; COM(2001)80 Final; European Commission: Brussels, Belgium, 2001.

137. André, P. The Role and Current Status of IFRS in the Completion of National Accounting Rules-Evidence from European Countries. Account. Eur. 2017, 14, 1-12. [CrossRef]

138. European Commission. Review of Country-By-Country Reporting Requirements for Extractive and Logging Industries. Final Report. November 2018. Available online: https:/ec.europa.eu/info/sites/info/files/business_economy_euro/company_reporting_and_auditing/ documents/181126-country-by-country-reporting-extractive-logging-industries-study_en.pdf (accessed on 1 November 2019).

139. European Commission. Proposal for a Directive of the European Parliament and of the Council Amending Directive 2013/34/EU as Regards Disclosure of Income Tax Information by Certain Undertakings and Branches; 12.4.2016, COM(2016) 198 Final, 2016/0107 (COD); European Commission: Brussels, Belgium, 2016.

140. European Parliament Resolution of 24 October 2019 on the State of Play on the Proposal for a Directive of the European Parliament and of the Council Amending Directive 2013/34/EU as Regards Disclosure of Income Tax Information by Certain Undertakings and Branches (2016/0107(COD)), Known as Public Country-By-Country Reporting (2019/2882(RSP)). Available online: www.europarl.europa.eu/doceo/document/TA-9-2019-0048_ EN.html (accessed on 1 June 2020).

141. Amendments Adopted by the European Parliament on 4 July 2017 on the Proposal for a Directive of the European Parliament and of the Council Amending Directive 2013/34/EU as Regards Disclosure of Income Tax Information by Certain Undertakings and Branches (COM(2016)0198, C8-0146/2016, 2016/0107(COD)). Available online: www.europarl.europa.eu/doceo/document/TA-8-2017-0284_EN.pdf (accessed on 1 June 2020).

142. Directive 2004/109/EC of the European Parliament and of the Council of 15 December 2004 on the Harmonisation of Transparency Requirements in Relation to Information about Issuers Whose Securities Are Admitted to Trading on a Regulated Market and Amending Directive 2001/34/EC; OJ L 390; European Commission: Brussels, Belgium, 2004; pp. 38-57.

143. Alliance for Corporate Transparency. 2019 Research Report: An Analysis of the Sustainability Reports of 1000 Companies Pursuant to the EU Non-Financial Reporting Directive. Available online: https://www.allianceforcorporatetransparency.org/assets/2019_Research_Report\%20_Alliance_for_ Corporate_Transparency-7d9802a0c18c9f13017d686481bd2d6c6886fea6d9e9c7a5c3cfafea8a48b1c7.pdf (accessed on 7 May 2020).

144. Directive 2014/56/EU of the European Parliament and of the Council of 16 April 2014 Amending Directive 2006/43/EC on Statutory Audits of Annual Accounts and Consolidated Accounts; OJ L 158, 27.5.2014; European Union: Brussels, Belgium, 2014; pp. 196-226. 
145. European Commission. Fitness Check on the EU Framework for Public Reporting by Companies. Available online: https://ec.europa.eu/info/consultations/finance-2018-companies-public-reporting_en (accessed on 1 November 2019).

146. European Commission. Summary Report of the Public Consultation on the Fitness Check on the EU Framework for Public Reporting by Companies. 21 March-31 July 2018. Ref. Ares(2018)5582266-31/10/2018. Available online: https://ec.europa.eu/info/sites/info/files/business_economy_euro/banking_and_finance/ documents/2018-companies-public-reporting-feedback-statement_en.pdf (accessed on 1 November 2019).

147. European Corporate Reporting Lab @ EFRAG. Available online: https://www.efrag.org/Activities/ 1807101446085163/European-Corporate-Reporting-Lab-at-EFRAG (accessed on 1 November 2019).

148. Regulation (EU) 2019/2088 of the European Parliament and of the Council of 27 November 2019 on Sustainability-Related Disclosures in the Financial Services Sector (Text. with EEA Relevance); PE/87/2019/REV/1; OJ L 317; European Union: Strasbourg, France, 2019; pp. 1-16.

149. European Financial Reporting Advisory Group. New EFRAG Consultation on Equity Instruments-Research on Measurement. 06/05/2019. Available online: http://www.efrag.org/News/Public-183/New-EFRAGconsultation-on-Equity-Instruments--Research-on-Measurement (accessed on 1 November 2019).

150. de Villiers, C.; Hsiao, P.-C.K.; Maroun, W. Developing a Conceptual Model of influences around Integrated Reporting: New Insights, and Directions for Future Research. Meditari Account. Res. 2017, 25, 450-460. [CrossRef]

151. Corporate Reporting Dialogue. Available online: http://corporatereportingdialogue.com (accessed on 1 November 2019).

152. Ogata, K.; Inoue, S.; Ueda, A.; Yagi, H. The Functional Differentiation Between the International Integrated Reporting Council (IIRC) and the Global Reporting Initiative (GRI) in the Sphere of Sustainability Reporting. In Accounting for Sustainability: Asia Pacific Perspectives; Springer: Berlin, Germany, 2018; pp. 261-279.

153. International Auditing and Assurance Standards Board, Extended External Reporting (EER) Assurance. Available online: www.iaasb.org/projects/extended-external-reporting-eer-assurance (accessed on 7 May 2020).

154. European Commission. Annex to the Communication from the Commission to the European Parliament, the European Council, the Council, the European Economic and Social Committee and the Committee of the Regions: The European Green Deal. 11.12.2019, COM(2019) 640 Final ANNEX. Available online: https: //ec.europa.eu/info/sites/info/files/european-green-deal-communication-annex-roadmap_en.pdf (accessed on 27 December 2019).

(C) 2020 by the author. Licensee MDPI, Basel, Switzerland. This article is an open access article distributed under the terms and conditions of the Creative Commons Attribution (CC BY) license (http://creativecommons.org/licenses/by/4.0/). 